Article

\title{
Sustainability of Village Tank Cascade Systems of Sri Lanka: Exploring Cascade Anatomy and Socio-Ecological Nexus for Ecological Restoration Planning
}

\author{
Sujith S. Ratnayake ${ }^{1,2, *(\mathbb{D}}$, Lalit Kumar ${ }^{3}{ }^{(}$, Punchi B. Dharmasena ${ }^{4}$, Harsha K. Kadupitiya ${ }^{5}(\mathbb{D}$, \\ Champika S. Kariyawasam ${ }^{1,2}{ }^{-1}$ and Danny Hunter ${ }^{6}(\mathbb{D})$ \\ 1 Ecosystem Management, School of Environmental and Rural Science, University of New England, \\ Armidale, NSW 2351, Australia; ckariyaw@myune.edu.au \\ 2 Ministry of Environment, Battaramulla 10120, Sri Lanka \\ 3 East Coast Geospatial Consultants, Armidale, NSW 2350, Australia; lkumar9@hotmail.com \\ 4 Faculty of Agriculture, Rajarata University of Sri Lanka, Mihintale 50300, Sri Lanka; \\ dharmasenapb@gmail.com \\ 5 Natural Resources Management Centre, Department of Agriculture, Peradeniya 20400, Sri Lanka; \\ kadupitiya@gmail.com \\ 6 Alliance of Bioversity International and CIAT, Via di San Domenico, 1, 00153 Rome, Italy; d.hunter@cgiar.org \\ * Correspondence: rratnay2@myune.edu.au; Tel.: +61-480-180-395
}

check for updates

Citation: Ratnayake, S.S.; Kumar, L.; Dharmasena, P.B.; Kadupitiya, H.K.; Kariyawasam, C.S.; Hunter, D. Sustainability of Village Tank Cascade Systems of Sri Lanka: Exploring Cascade Anatomy and Socio-Ecological Nexus for Ecological Restoration Planning. Challenges 2021, 12,24. https://doi.org/10.3390/ challe12020024

Academic Editor: Susan L. Prescott

Received: 15 July 2021

Accepted: 9 September 2021

Published: 23 September 2021

Publisher's Note: MDPI stays neutral with regard to jurisdictional claims in published maps and institutional affiliations.

Copyright: (c) 2021 by the authors Licensee MDPI, Basel, Switzerland. This article is an open access article distributed under the terms and conditions of the Creative Commons Attribution (CC BY) license (https:// creativecommons.org/licenses/by/ $4.0 /)$.

\begin{abstract}
Village Tank Cascade Systems (VTCSs) in the Dry Zone of Sri Lanka have evolved as sustainable ecosystems through human interventions to ensure water availability and other services for people and their environs during the last few millennia. However, VTCSs are vulnerable to global environmental changes resulting in continual deterioration of ecological health and hydro-socioecological status, crucial for the food and livelihood security of rural farming communities in the dry zone. This paper seeks to explore resource systems of the Mahakanumulla VTCS located in Anuradhapura district of Sri Lanka to (i) identify the spatial metrics linked to the sustainability and socio-ecological resilience of the VTCS, and (ii) determine interactions among system elements and their impacts on productivity and restoration challenges. The spatial analysis was conducted using a Digital Elevation Model (DEM), recent digital topographic map layers and Google Earth images to understand the spatial distribution and ensemble of tank environs. Participatory field assessment data were also used to determine socio-ecological nexus and factors that contribute to the reduction of ecological productivity of VTCS. The study revealed that the ensemble of tank environs is significant for providing regulatory and supporting ecosystem services (ES) and synergistic relationships with provisional ES of the VTCS. Results also revealed that the complex land-water-biodiversity-climate and food nexus that determines the productivity of the VTCS could be adopted in VTCS ecological restoration planning. The study presents a comprehensive framework to analyse causal factors and processes leading to reduction of overall productivity linked with variables of socio-ecological properties, vulnerability and resilience of the VTCS landscape.
\end{abstract}

Keywords: village tank cascade system; socio-ecological nexus; cascade anatomy; cascade ensemble; ecological productivity; ecological restoration; socio-ecological resilience

\section{Introduction}

Surface runoff water harvesting systems through small tanks in micro-watersheds are found in several Mediterranean and Asian countries [1]. In order to achieve the targets of the Sustainable Development Goals especially SDG-2 and SDG-6, it is vital to restore these systems using community participation to enhance surface and groundwater management, especially in developing countries [2-4]. The Village Tank Cascade System (VTCS) is a complex socio-ecological system existing in the Dry and Intermediate Zones of Sri Lanka. In the country, the VTCS bears unique features, not only hydrological and 
physiological aspects but also deeply interwoven elements with socio-hydro-ecological characteristics of the landscape, ensuring their sustainability and socio-ecological resilience. The VTCS was first defined as a 'connected series of village tanks organized within a meso-catchment of the dry zone landscape, storing, conveying and utilizing water from an ephemeral rivulet' [5]. However, it was found that the functionality and concept of the VTCS go beyond its water-based ecosystem services. Considering its ecological functions and socio-ecological production outcomes, a new interpretation has been provided by Dharmasena [6] as 'an ecosystem where water and land resources are organized within the micro-catchments of the dry zone landscape, providing basic needs to human, floral and faunal communities through water, soil, air and vegetation with human intervention on sustainable basis'. VTCS is considered one of the oldest and most advanced agricultural irrigation systems that has evolved in the world $[7,8]$. More than 14,000 small village tanks are still in use in the Dry and Intermediate Zones of Sri Lanka, with an irrigation potential of about 246,540 ha of paddy lands [6,9]. Revitalization of VTCSs is essential for achieving climate resilience and food security in these peasant communities of Sri Lanka.

The resilient properties and adaptive capacity of these systems have been realized for more than several millennia. The VTCS provides a classic example of how human wellbeing can overcome the natural shocks of the past two millennia in harmony with nature employing practices preserving biodiversity and ecosystem services [8]. Considering its unique landscape and ecological features harmonized with the local culture and human life, the VTCS was been declared as a Globally Important Agricultural Heritage Systems (GIAHSs) by the United Nations Food and Agriculture Organization (FAO) in 2018 [10]. Global environmental initiatives, which have dealt with socio-ecologically sensitive production landscapes (SESPLs), have shown keen interest in studying the multifaceted values of these Village Tank Cascade Systems (VTCSs) [11,12]. Several international funding agencies, such as the Green Climate Fund (GCF) and the Global Environment Facility (GEF) have initiated projects with government and non-government stakeholders for restoration of these systems, taking into consideration the capacity of the system to address climate change impacts for sustainable rural livelihoods in the Dry Zone of Sri Lanka.

A VTCS cannot be simplified to its physical structures and practices. Besides providing irrigated water for paddy cultivation, these small tank systems play significant socio-ecological, socio-cultural, and socio-economic roles in the livelihoods of rural farmers and communities. The impairment of VTCS hydro-socio-ecology functioning, mainly due to climate, land use and demographic changes, has significantly impacted the sustainability of the system. Recent restoration efforts carried out by different agencies have not analysed systematically the socio-ecological nexus and functions, ecologically important micro-land uses and their spatial connections. This has caused unintended degradation to cascade anatomy during various VTCS rehabilitation projects. Better understanding these characteristics is important in determining causal factors of the reduction of ecological productivity of the VTCS. However, little research has been undertaken to study the cascade ecology of the VTCS landscape at different scales and to understand the capacity of providing ES at the landscape level. In addition, while several studies of VTCSs have focused on specific subject areas such as soil and water properties [13-15], hydrology [16-22], limnology $[7,23,24]$ and sedimentology $[25,26]$, there have been hardly any systematic studies undertaken to analyse socio-ecological system characteristics, functions, and interactions based on a system thinking approach. Therefore, this study aims to address this research gap by evaluating the spatial and socio-ecological nexus in the Mahakanumulla VTCS located in Anuradhapura District of Sri Lanka. The specific objectives of this study were to (i) explore the spatial distribution pattern and cascade anatomy of VTCS in Sri Lanka, (ii) identify subsystems, variables, and interactions between system properties in terms of the land-water-biodiversity-climate and food nexus, and (iii) identify causal factors and nexus that contribute to the reduction of ecological and socio-economic productivity of the system. 


\section{Materials and Methods}

\subsection{Study Area}

The Mahakanumulla VTCS, which is one of the VTCSs found in the Nachchaduwa reservoir watershed in the Anuradhapura district, was selected to study the cascade anatomy and socio-ecological nexus (Figure 1). The entire Dry Zone landscape of Sri Lanka was selected to explore the spatial distribution patterns of the VTCSs.

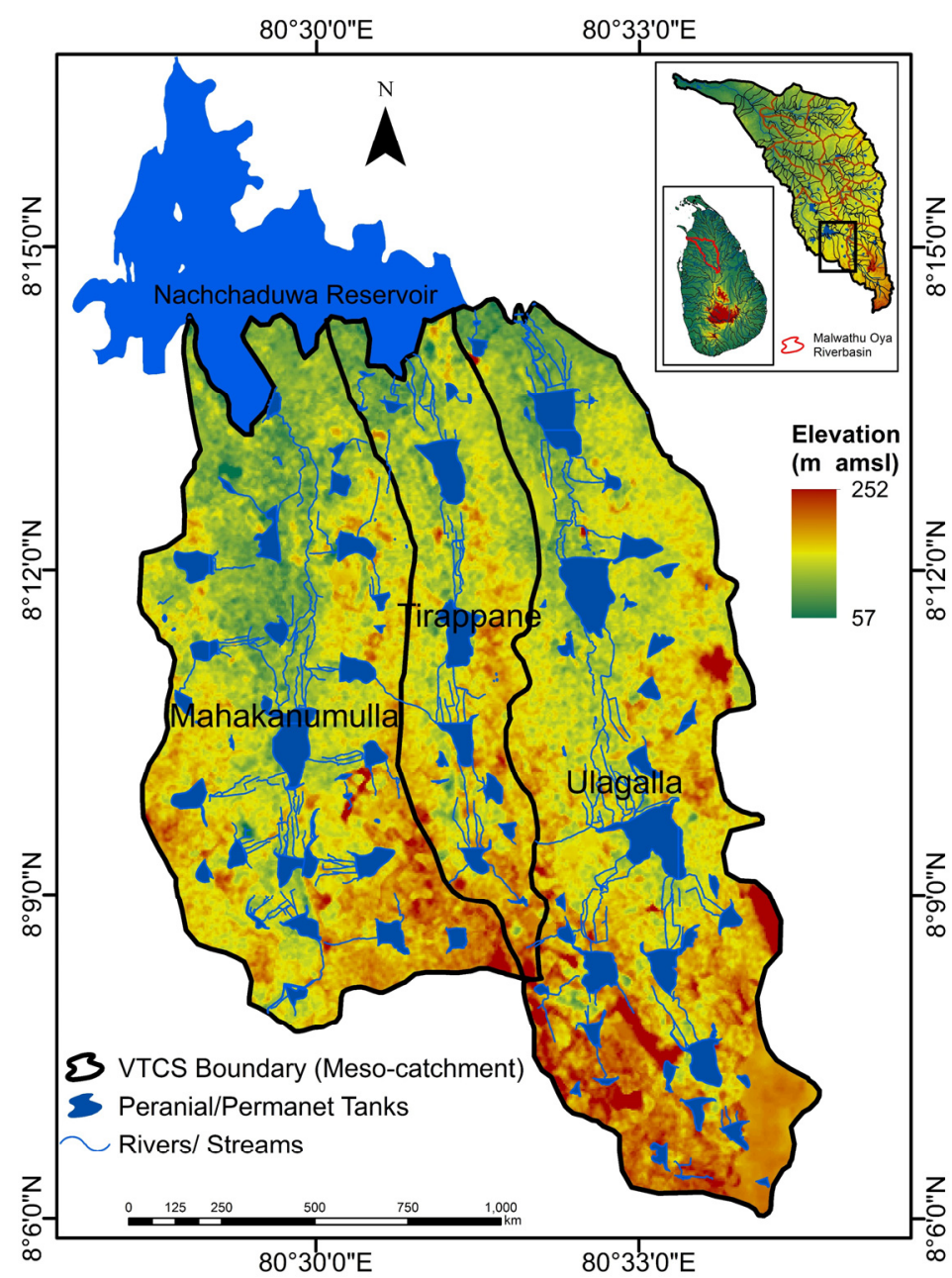

Figure 1. Mahakanumulla VTCS located in the Nachchaduwa reservoir watershed.

\subsection{Data Collection Sources}

The spatial data sources used to achieve the specific objective (i) in this study included (a) Global Digital Elevation Model V003 (30 m), 2018, accessed 5 January 2021 from https: / / doi.org/10.5067/ASTER/ASTGTM.003 and (b) digital map layers of different spatial levels and scales obtained from Department of Agrarian Development of Sri Lanka, Land Use Policy Planning Department of Sri Lanka and Survey Department of Sri Lanka. Nonspatial data and information used for the specific objectives (ii) and (iii) in this study were extracted from field assessment and survey reports of the study area $[27,28]$ and past studies and resource profiles of the Mahakanumulla VTCS. On-site spatial assessments and field verification surveys were carried out in November and December 2020.

\subsection{Exploration of Spatial Distribution Pattern and Spatial Relationships}

In order to achieve the specific objective (i), this study assessed and mapped the distribution of VTCSs at the country level, and identified the spatial setting of biophysical components at the VTCS level. Under this task, spatial analysis was performed using ArcGIS for different hierarchical levels from national to VTCS micro-catchment levels 
(Figure 2). Spatial analysis for mapping was carried out using Digital Elevation Model and digital maps were prepared for land use and land cover (LULC), river basins, cascade systems and village tanks. Further, fine-scale maps of LULC and tank components were developed using a Google Earth image accessed on 23 January 2021 as base maps, and on-screen digitizing was made by employing ArcMap (version 10.8.1) software from Environmental Systems Research Institute, Redlands, California, USA. The results were validated through on-site field verifications assessments and surveys, aerial drone images and making references to resource profiles of the Mahakanumulla VTCS landscape. The onsite spatial assessments and field verification surveys were done in collaboration with the Ministry of Environment, Department of Agriculture and Wayamba University of Sri Lanka under a GEF-funded project on 'Managing Agricultural Landscapes in Socio-ecologically Sensitive Areas to Promote Food Security, Well-being and Ecosystem Health-Healthy Landscapes Project' (HLP) (https://www.thegef.org/projects, accessed on 20 January 2021) [28].

Spatial levels

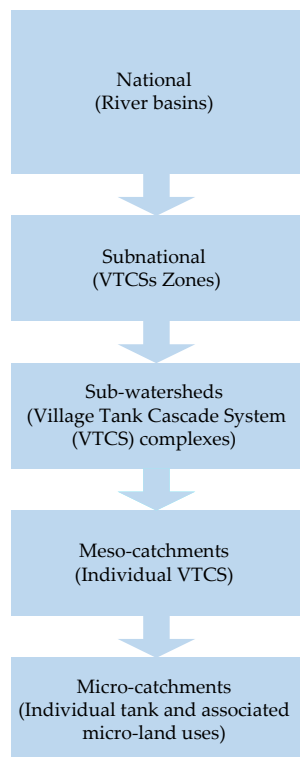

Objectives

$$
\begin{aligned}
& \text { Evaluate spatial placement of } \\
& \text { Village Tank Cascade Systems } \\
& \text { (VTCSs) in relation to spatial } \\
& \text { distribution of water regime } \\
& \text { Evaluate spatial clustering } \\
& \text { pattern of VTCSs within a } \\
& \text { VTCSs Zones } \\
& \text { Evaluate spatial clustering } \\
& \text { pattern of village tanks within } \\
& \text { a sub-watershed } \\
& \text { Evaluate spatial organization of } \\
& \text { village tanks, macro and micro- } \\
& \text { land uses within a VTCS } \\
& \text { Evaluate spatial setting of } \\
& \text { village tank and associated } \\
& \text { micro-land use components } \\
& \text { within micro-catchments }
\end{aligned}
$$
of a VTCS
GIS Techniques

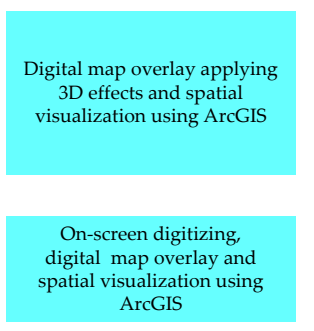

On-screen digitizing,

digital map overlay and

spatial visualization using
ArcGIS
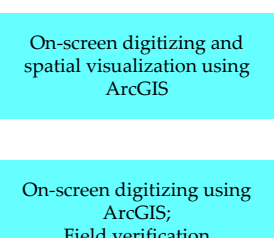

Spatial data

National Level $(1: 200,000)$ - River basins map *

- Surface water layer **

- Digital Elevation Model***

- VTCSs digital map*

Subnational level $(1: 50,000)$

- Village tanks digital map*

- Surface water layer**

- Infrastructure layer**

Sub-watersheds level $(1: 10,000)$

- River basins/sub-watersheds map*

- Village tanks digital map

- Surface water layer

- Land use layer+

- Google Earth images

VTCS level $(1: 10,000)$

- Village tanks digital map*

- Surface water layer

- Land use layer+

- Google Earth images

Tank micro-catchment maps (1:1000)

- Individual tank catchments++

- Land cover++

- Google Earth image
Outputs

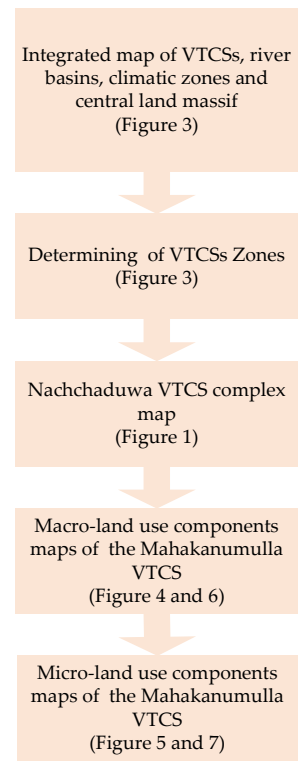

Data origin: *Digital data from Department of Agrarian Development of Sri Lanka; ** Digital data from Survey Department of Sri Lanka; ***ASTER Global Digital Elevation Model V003 $(30 \mathrm{~m}), 2018$, accessed 5 January 2021 from https://doi.org/10.5067/ASTER/ASTGTM.003; $\sim$ Maps developed using ArcGIS spatial analysis; + Digital data from Land Use Policy Planning Department of Sri Lanka; ++ Maps developed using on screen digitizing on Google Earth images.

Figure 2. Flow diagram of methodology for spatial analysis and mapping.

\subsection{Exploration of Interactions among System Properties}

The interactions among the VTCS properties (specific objective ii) were identified by studying socio-ecological subsystems and components of the VTCS and mapping the interactions (nexus) between them in the Mahakanumulla VTCS. The process involved (a) identifying subsystems and their components, (b) unveiling interactions and issues among subsystems' components and (c) obtaining feedback from key informants and experts on the interactions and issues relevant to the ecological and socio-economic productivity outcomes of the VTCS. The study used data and information from participatory field assessments and surveys conducted by the HLP $[27,28]$.

\subsection{Identification of Productivity Issues, Linked with Socio-Ecological Properties and Restoration Challenges}

The specific objective (iii) of the study was achieved through the identification of specific causal factors that contribute to the reduction of ecological and socio-economic productivity and mapping the relationships among the identified causal factors. Specific causal factors and interactive relationships were identified during the field assessments 
and surveys of biodiversity, medicinal plants ecosystem services, land degradation and food security conducted by the expert team of the HLP [27,28]. Identified causal factors were prioritized through on-site participatory assessments in the study site. The impact of drivers of change related to climate variability and land use and cover changes were identified through past studies conducted in the study area. The data and information extracted from the field assessments were analysed to determine the implications of direct and indirect relationships among the identified causal factors and indicators based on socio-ecological vulnerability, adaptive capacity and socio-ecological resilience framework to determine ecological restoration strategies [29].

\section{Study Findings and Discussion}

\subsection{Spatial Distribution Pattern and Spatial Relationships \\ 3.1.1. Spatial Distribution of VTCSs in Sri Lanka}

The evolutionary process of VTCSs is mainly inspired by three main factors of the dry zone landscape: (i) geomorphology; (ii) hydrology and (iii) the nature of the substratum (pedology, geology, lithology) [30]. The river basins associated with VTCSs experience a rainwater deficit in one season and a surplus during the other season [30,31]. In this context, VTCSs were built taking into consideration the natural geomorphology of the landscape to ensure the availability of water resources throughout the year. There are 1,162 VTCSs identified in Sri Lanka, of which more than $85 \%$ of the VTCSs are found at an elevation range of 100-300 m amsl. The majority of VTCSs (90\%) are clustered into three major zones, namely North and North-central, North-western, and South and South-eastern [6]. The zones are characterized by hills and valleys supported by water movement, shape and the size of the micro-watersheds. The GIS spatial analysis found that the three VTCSs zones, which represent $21.7 \%$ of the country, contribute to $23.3 \%$ of paddy lands in Sri Lanka.

Though there are 103 river and major stream basins recorded in Sri Lanka, many of them do not originate from the Central Mountainous Land Massif (CMLM) [32]. The GIS spatial analysis of this study indicated that river basins, which contain the majority of the VTCSs do not have direct surface hydrological connectivity with the CMLM of the country (Figure 3). The area of surface water origin of each river basin was divided into three levels of administrative divisions: Grama Niladhari (GN) division, Divisional Secretariat (DS) division and District Secretariat level (Table 1).

Rainfall regime and water budget are significant factors for determining the agricultural and ecological productivity of the VTCS landscapes. The annual average rainfall in the VTCS study area is $1445 \mathrm{~mm}$, with a temporal variation from 875 to $1875 \mathrm{~mm}$. The distribution is characterized by a well-defined bi-modal rainfall pattern. The evaporation from the free water surface ranges from 3.5 to $7.5 \mathrm{~mm} /$ day, and the average daily ambient temperature is $27^{\circ} \mathrm{C}[15,33]$. This indicates water is a limiting factor for agricultural productivity in the VTCS area. The amount and distribution pattern of the rainfall creates four climatic seasons (with two major cultivation seasons) in a year. Highly distinct rainfall regimes, seasonality and water stress have contributed to the evolution of diverse agricultural land use and cropping patterns of the VTCS landscape. [30,34,35]. Substratum features of the VTCSs zones favourably contribute to surface drainage patterns and groundwater availability of the area. Major soil groups (Reddish Brown Earths (60\%), Low Humic Gley (30\%) and alluvial (10\%)) found in the VTCS with distinctly different drainage conditions create the optimum environmental conditions for farmers to adopt a three-fold farming system (lowland paddy, rainfed upland and homestead) in the VTCS. A highly impervious shallow regolith aquifer found in the VTCS area is recharged by seasonal precipitation and seepage from tanks, rivers, and streams continuously throughout the year [30,34,35]. Thus, the above geomorphological. hydrological and substratum features could contribute immensely to reducing the risk of natural disasters, especially climatic stresses in the VTCS. The whole ecological and agricultural productivity in the VTCS is governed by these features. 


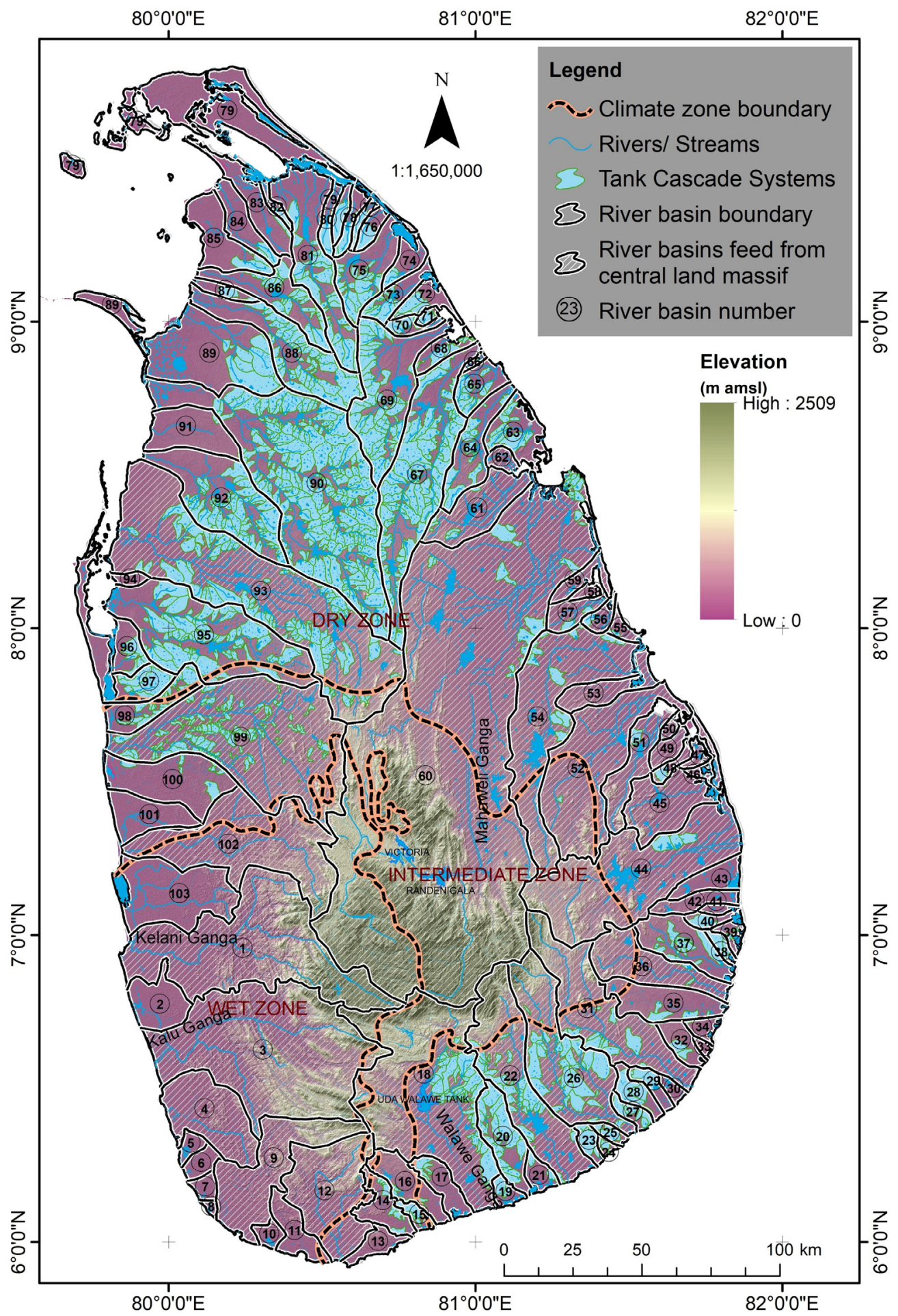

Figure 3. Map showing clusters of tank cascade systems, river basins, central mountainous land massif, and main climatic zones of Sri Lanka. 
Table 1. Distribution of VTCSs in river basins of Sri Lanka.

\begin{tabular}{|c|c|c|c|c|c|c|}
\hline \multirow[b]{2}{*}{$\begin{array}{c}\text { Main Cascade } \\
\text { Zone }\end{array}$} & \multirow[b]{2}{*}{ River Basin } & \multirow[b]{2}{*}{$\begin{array}{c}\text { River Basin } \\
\text { No }\end{array}$} & \multirow[b]{2}{*}{$\begin{array}{c}\text { Number of } \\
\text { VTCSs * }\end{array}$} & \multicolumn{3}{|c|}{ Area of Origin ** } \\
\hline & & & & GN Division & DS Division & $\begin{array}{c}\text { District } \\
\text { Secretarit }\end{array}$ \\
\hline \multirow{15}{*}{$\begin{array}{l}\text { North and } \\
\text { North-central }\end{array}$} & $\begin{array}{c}\text { Malwathu } \\
\text { Oya }\end{array}$ & 90 & 189 & Demunnewa & Palugaswewa & Anuradhapura \\
\hline & Kala Oya & 93 & 91 & Palapathwala & Galewela & Matale \\
\hline & Yan Oya & 67 & 80 & Habarana & Ritigala & Anuradhapura \\
\hline & Мa Oya & 69 & 45 & Thurukkuragama & Kahatagasdigiliya & Anuradhapura \\
\hline & $\begin{array}{c}\text { Modaragam } \\
\text { Aru }\end{array}$ & 92 & 45 & Kadurugaswewa & Thalawa & Anuradhapura \\
\hline & Paranki Aru & 88 & 36 & Madukanda & Kebithigollewa & Vavuniya \\
\hline & $\begin{array}{c}\text { Mahaweli } \\
\text { Ganga }\end{array}$ & 60 & 28 & Ohiya & Welimada & Badulla \\
\hline & $\begin{array}{c}\text { Kanakarayan } \\
\text { Aru }\end{array}$ & 81 & 23 & Kallikulam & Vavuniya & Vavuniya \\
\hline & Pali Aru & 86 & 18 & $\begin{array}{l}\text { Puliyankulam } \\
\text { Noth }\end{array}$ & Vavuniya North & Vavuniya \\
\hline & Per Aru & 75 & 17 & Olumadu & Vavuniya North & Vavuniya \\
\hline & $\begin{array}{c}\text { Pankulam } \\
\text { Aru }\end{array}$ & 64 & 12 & $\begin{array}{c}\text { Galmetiyawa } \\
\text { North }\end{array}$ & Horowpothana & Trincomalee \\
\hline & Panna Oya & 63 & 9 & Morawewa South & Morawewa & Trincomalee \\
\hline & $\begin{array}{l}\text { Kunchikumban } \\
\text { Aru }\end{array}$ & 65 & 9 & Galkadawala & Gomarankadawela & Trincomalee \\
\hline & Mannal Aru & 73 & 8 & Olumadu & Vavuniya North & Vavuniya \\
\hline & Nay Aru & 89 & 7 & Velankulam & Vengalacheddiculam & Vavuniya \\
\hline \multirow{3}{*}{ North-western } & Deduru Oya & 99 & 164 & Kirindiwelpola & Thumpane & Kandy \\
\hline & Mi Oya & 95 & 67 & Moragaswewa & Hingurakgoda & Kurunegala \\
\hline & $\begin{array}{c}\text { Rathabala } \\
\text { Oya }\end{array}$ & 98 & 24 & Moragolla & Kotavehera & Kurunegala \\
\hline \multirow{9}{*}{$\begin{array}{l}\text { South and } \\
\text { South-eastern }\end{array}$} & $\begin{array}{c}\text { Walawe } \\
\text { Ganga }\end{array}$ & 18 & 49 & Pattipola & NuwaraEliya & NuwaraEliya \\
\hline & Menik Ganga & 26 & 36 & Pallegama & Passara & Badulla \\
\hline & Kirinda Oya & 22 & 32 & Ranakeliya & Ella & Hambantota \\
\hline & Mallala Oya & 20 & 18 & Balaharuwa & Wellawaya & Monaragala \\
\hline & Karanda Oya & 37 & 12 & Kotagoda & Siyambalanduwa & Monaragala \\
\hline & $\begin{array}{c}\text { Kubukkan } \\
\text { Oya }\end{array}$ & 31 & 9 & Udakiruwa & Lunugala & Badulla \\
\hline & Kirama Oya & 14 & 7 & Radani Ara & Walasmulla & Hambantota \\
\hline & $\begin{array}{c}\text { Urubokka } \\
\text { Oya }\end{array}$ & 16 & 7 & Urubokka & Pasgoda & Matara \\
\hline & Maduru Oya & 54 & 7 & Dehigama & Rideemaliyadda & Badulla \\
\hline
\end{tabular}

* Data from [6], ** GIS spatial analysis.

3.1.2. Ensemble of the Cascade System and Its Anatomy

A village tank cascade system is an ensemble of various sizes of tanks interacting hydrologically, ecologically, and socially to form the cascade anatomy, which creates 
dynamic relationships. A GIS spatial analysis of the study mapped the organization of tanks and spatial setting of ecologically important components in the Mahakanumulla VTCS, with their relative positions, is presented in Figures 4 and 5. In the Mahakanumulla meso-catchment, hydro-ecologically interconnected tanks facilitate efficient re-use of water from an upstream command area to the next lower tank. This contributes to an increase in the water use efficiency for agricultural activities in the meso-catchment [36]. Further, the tank systems perform together with socio-ecological components of the VTCS, while providing basic needs to humans and enhancing the surrounding flora and fauna.

Macro and micro land-use components and their configuration are crucial for the resilience and sustainability of the system. The functions of macro and micro land-use components are interconnected, and their functions are important for the ecological stability of the system. Ecologically important micro-land uses and their functions are discussed in Table 2. Disruption of these ecological functions significantly interrupts the harmony between micro and meso-catchment characteristics of VTCS landscapes. Therefore, the sustainability and productivity of the VTCSs are dependent on a holistic understanding of the micro-land uses and their associated functions.

Table 2. Ecologically important micro-land uses of the tank system and their functions.

\section{Micro-Land Uses}

Upstream immediate catchment (Wew-ismaththa)

Upstream tree belt (Gasgommana) and undergrowth meadow- water filter (Perahana)

\section{Ecological Function}

This is the area located just above the Gasgommana. It is an open area with few bushes and trees. It is above the High Flood Level (HFL) around the upstream portion of the tank bed. It raises the groundwater table through percolation and gradually releases water to the tank through subsurface flow. Further, it filters sediments and adsorps pollutants through phytometric trees.

Uppermost part of the tank bed, where arrays of sedges and shrubs are grown. It slows down the inflow to the tank, holds suspended sediment and absorbs pollutants and reduces toxicity reaching the tank.

It provides habitat for birds and enhances biodiversity.

Gasgommana is a strip of trees found at the periphery of the tank bed functioning as a wind barrier, which reduces the evaporation and temperature of the water body.

The roots and rootlets of large trees make water cages creating a favourable environment for fish breeding.

The meadow underneath Gasgommana (Perahana) filters the suspended silt transported from upstream Chena lands and demarcates the territory between humans and wild animals.

Creates habitat for birds and small wild animals.

Traps sediment and allows clean water to enter the tank.

Provides water to wild animals and domestic cattle during dry periods. Minimize the threats from wild animals.

Upstream water holes (Godawala) and forest tank (Kuluwewa)

Creates harmony for coexistence between elephants and village inhabitants. Supports raising the groundwater table.

\begin{tabular}{|c|c|}
\hline Upstream soil ridges (Iswetiya or potawetiya) & $\begin{array}{l}\text { Slows down and diverts inflow coming from relatively sloping lands (at present } \\
\text { tanks are heavily sedimented due to the absence of these soil ridges). }\end{array}$ \\
\hline $\begin{array}{l}\text { Downstream reservation- Interceptor } \\
\text { (Kattakaduwa) }\end{array}$ & $\begin{array}{l}\text { Creates diverse vegetation, as this land strip has four micro-climatic phases. } \\
\text { Acts as a natural bio-filter absorbing salts and ferric ions in seepage water before it } \\
\text { moves into the paddy fields. }\end{array}$ \\
\hline $\begin{array}{l}\text { Common drainage (Kiul- ela and Flora along } \\
\text { the Kiul-ela) }\end{array}$ & $\begin{array}{l}\text { Acts as the common drainage of the paddy field for removing salts and ferric ions } \\
\text { to improve the soil fertility of the paddy tract. }\end{array}$ \\
\hline $\begin{array}{l}\text { Backyard reservation around the hamlet } \\
\text { (Tis-bambe) }\end{array}$ & $\begin{array}{l}\text { Used for sanitary purposes and as a resting place for buffaloes. } \\
\text { Buffaloes protect dwellers from wild animals and malaria. }\end{array}$ \\
\hline $\begin{array}{l}\text { Land strips across paddy fields } \\
\text { (Kurulu-paluwa) }\end{array}$ & $\begin{array}{c}\text { A strip of paddy land left unharvested and dedicated for birds, cattle, and wild } \\
\text { herbivores as a ritual. } \\
\text { Attracts birds who ultimately control pests in paddy fields. }\end{array}$ \\
\hline
\end{tabular}




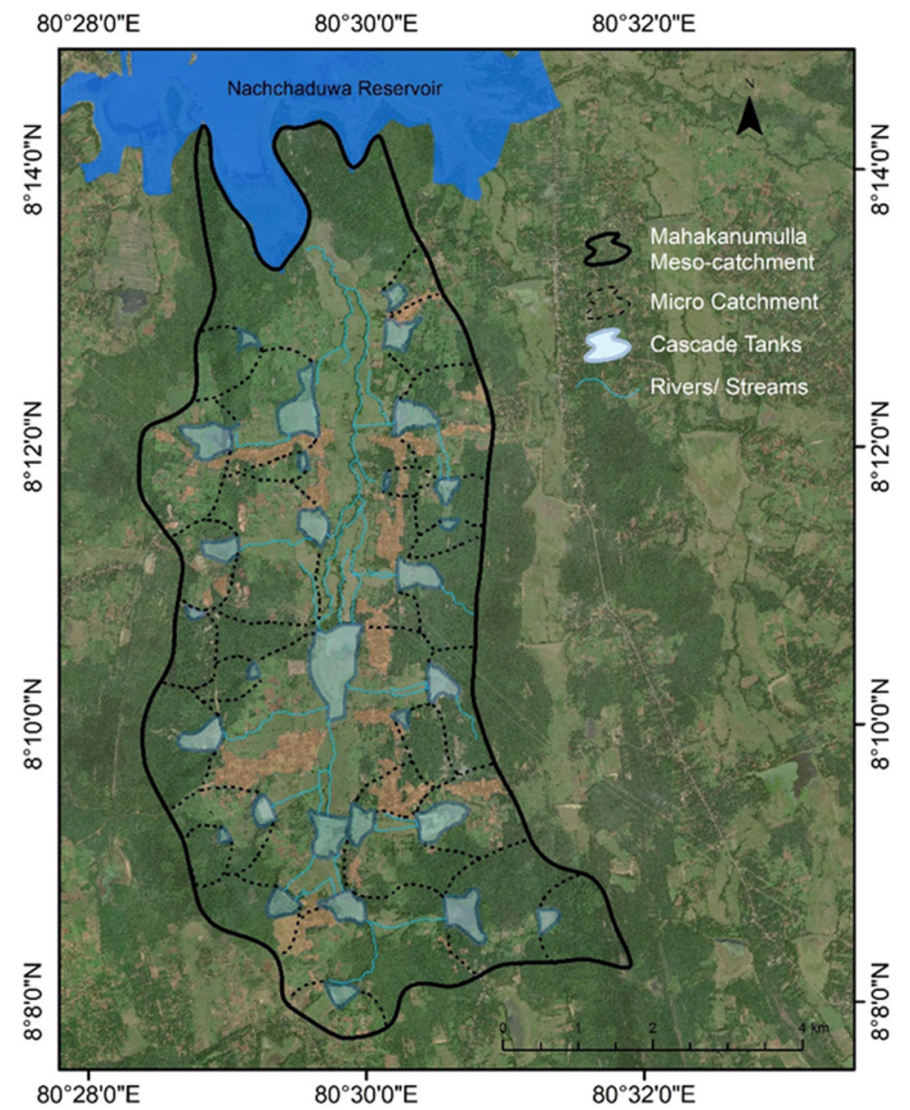

Figure 4. Organization of village tanks and micro-catchments in the Mahakanumulla VTCS.

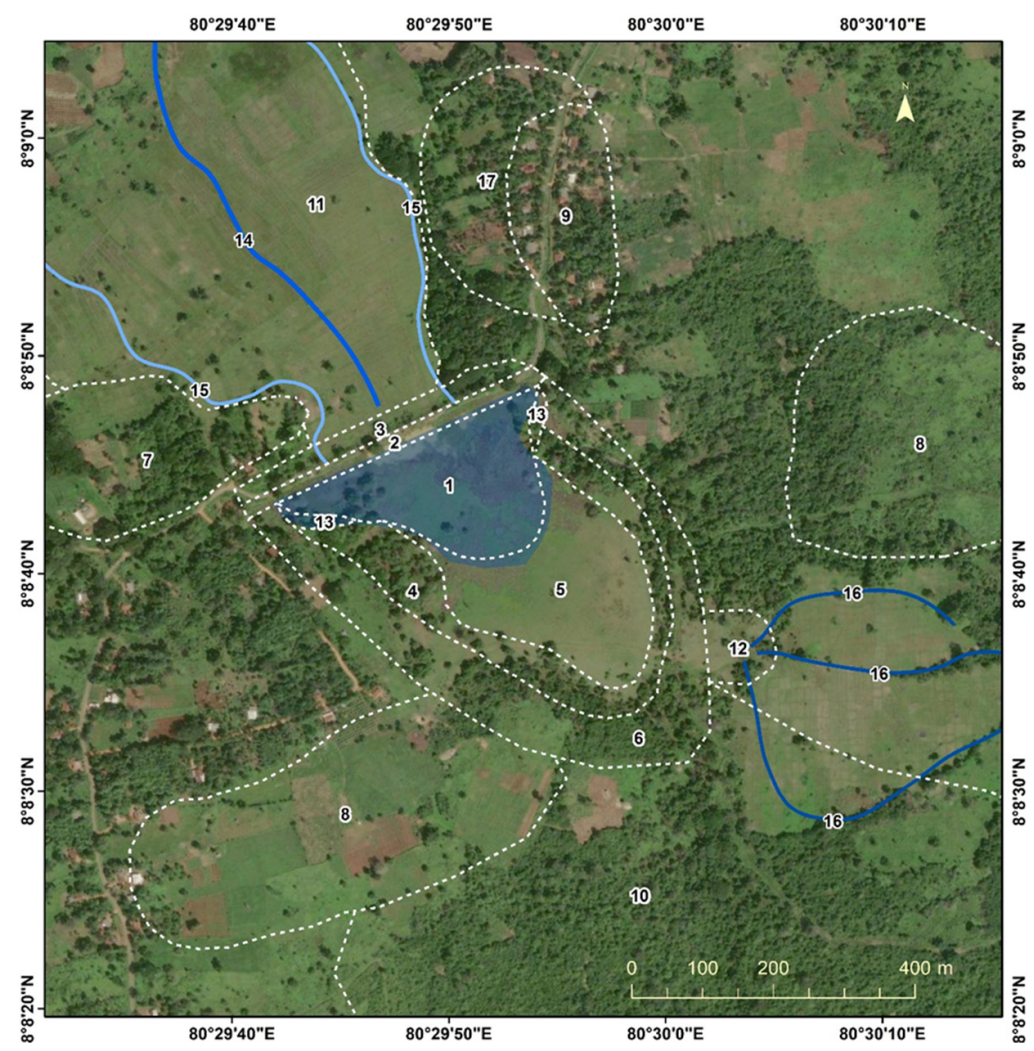

Figure 5. The spatial setting of tank associated micro-land use components within a selected microcatchment in the Mahakanumulla VTCS. 
The system components in Figure 5 include: $1=\operatorname{tank}$ bed; $2=\operatorname{tank}$ bund; $3=$ downstream reservation (Kattakaduwa); $4=$ upstream tree belt (Gasgommana); $5=$ upstream shallow tank bed (Wew-thaulla); 6 = upstream immediate catchment (Wew-ismaththa); $7=$ shrubland (Landa); $8=$ rainfed farmland (Hena); $9=$ hamlet (Gangoda); $10=$ upper catchment forest; 11 = command area paddy fields; $12=$ upstream water-hole (Godawala); 13 = soil ridge (Iswetiya); 14 = common drainage (Kiwul-ela); 15 = irrigation canal; 16 = stream (Ela); 17 = backyard reservation around hamlet (Tis-bambe).

\subsubsection{Understanding the Spatial Metric of the VTCS}

Different landscape components of the VTCS can have different levels of species richness and functions [38,39]. Hence, proper assessment of landscape indices such as spatial pattern and spatial configuration is important to understand how they affect the landscape processes and relationships when certain changes occur in these indices [40-42]. Based on the spatial analysis of the study, socio-ecologically important mosaic of land uses and hydro-ecologically integrated tanks in the Mahakanumulla VTCS create a specific spatial pattern as shown in Figures 6 and 7. Landscape variability-multi-functionality (number of land-use types per unit area) and landscape heterogeneity (number of land-use patches with the same number of land use classes per unit area) are considered key features of evaluating landscape mosaic patterns [43]. In addition, connectivity, shape, biotope types, and eco-tone length per unit area can be taken as indicators of evaluating the VTCS landscape variability and heterogeneity $[40,43]$. More diverse landscapes are generally more resilient to climatic change than landscapes with lower diversity [44].

Land uses of the socio-ecological systems can be classified based on basic ecological land cover units (e.g., community protected forests, pastures and natural grassland, forest, wetlands, water, plantations), social and cultural units (e.g., local people, traditional knowledge, culture), production systems (e.g., crop and livestock farming, agroforestry, urban agriculture, peri-urban agricultural, home-gardens, inland water associated fisheries), and relief, altitude and slope characteristic (e.g., mountain, highland, lowland, coastal river systems) [45-47]. The land use map generated for this study revealed that the Mahakanumulla VTCS comprises most of the above spatial features, providing an environment with multiple livelihood opportunities to the people [6,37]. 


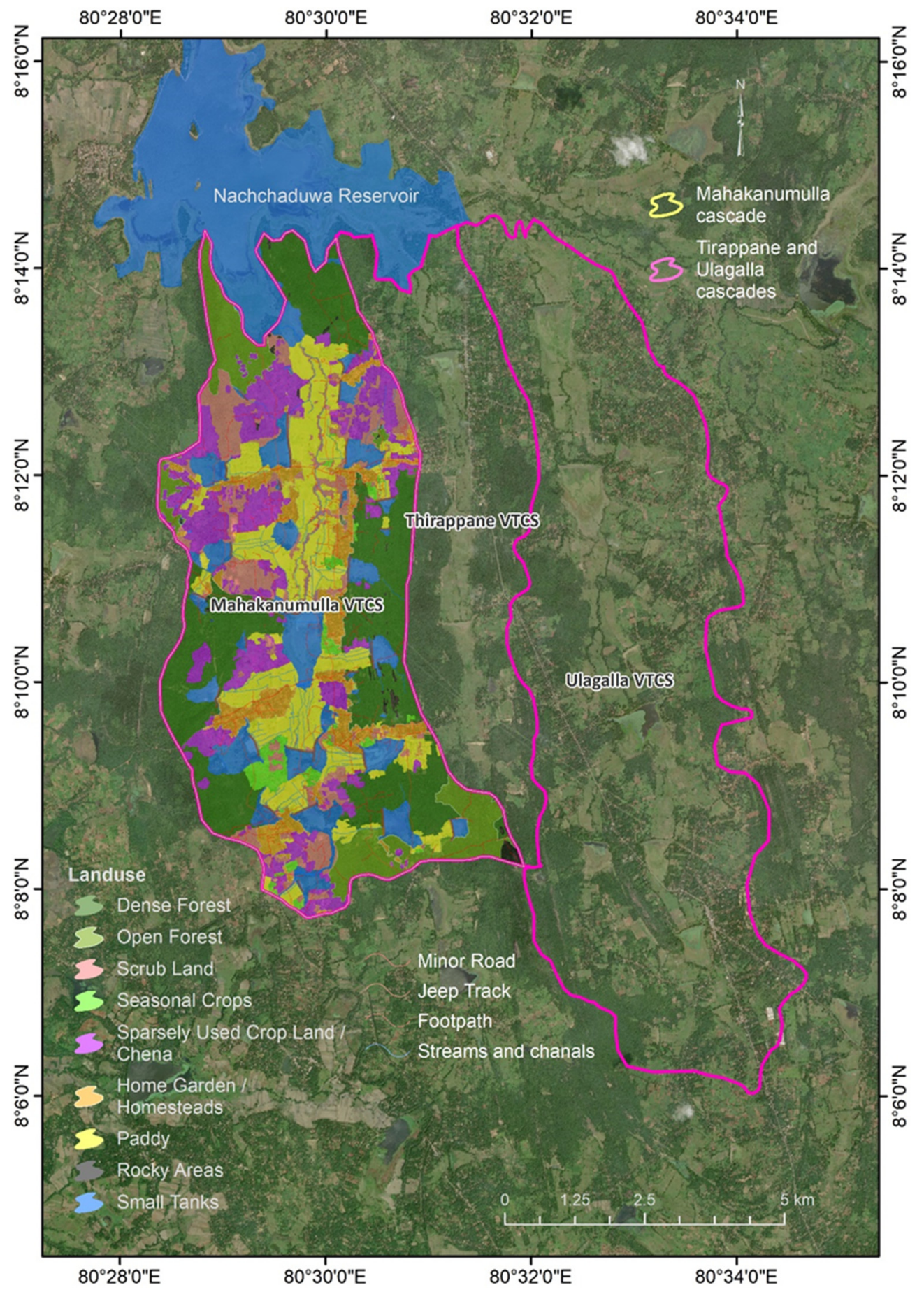

Figure 6. Mosaics of land use patterns found in the Mahakanumulla VTCS. 


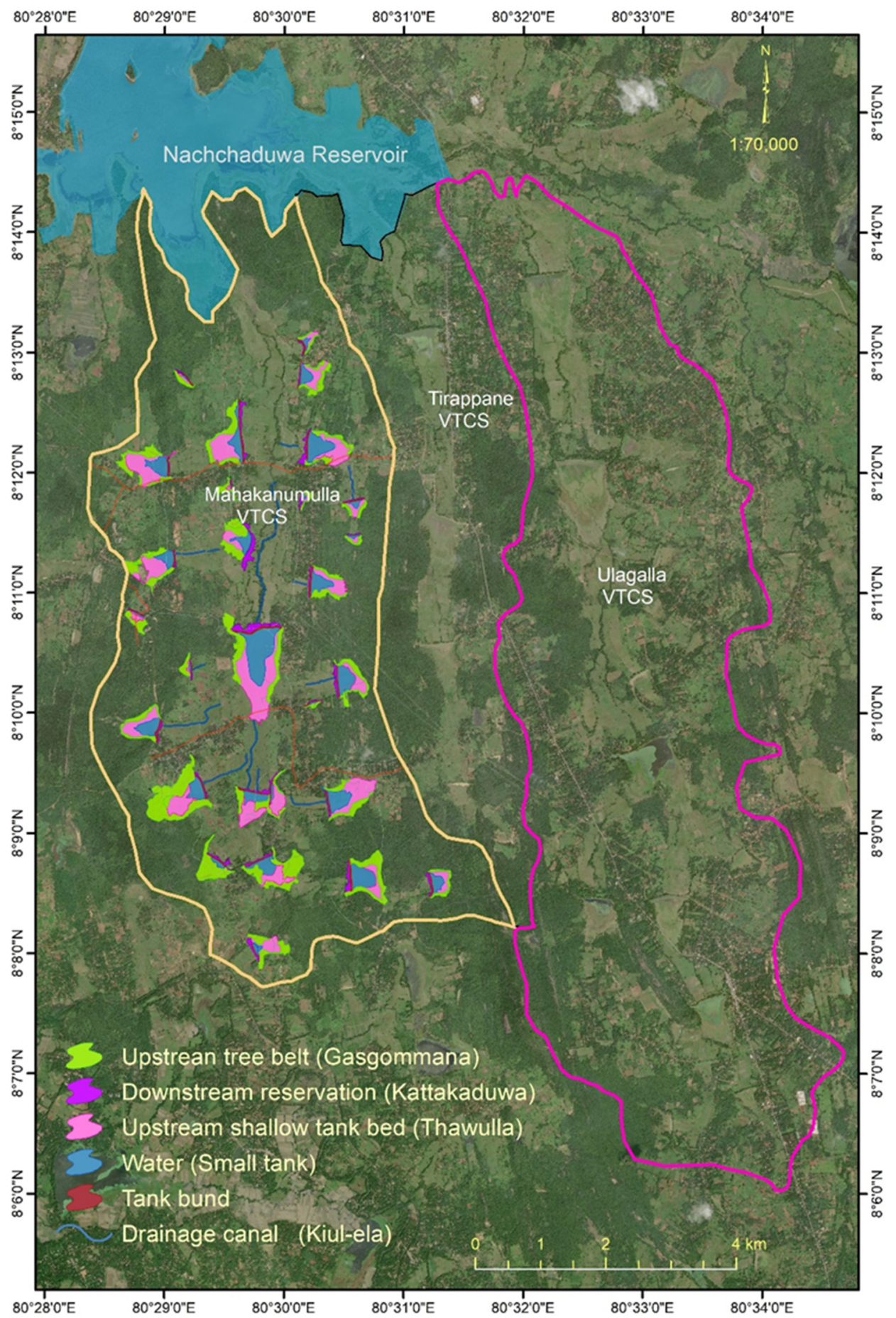

Figure 7. Spatial configuration of village tanks and associated micro-land use components in the Mahakanumulla VTCS.

\subsection{Interactions among System Properties}

\subsubsection{Land-Water-Food Security Nexus}

Water and land resources are the most critical elements in the VTCS processes as they are multifunctional and multipurpose and directly linked to the system productivity assuring the sustainability of food production [48]. The study analysed the on-site field assessments data (biodiversity, land degradation), linked with information extracted from the participatory assessments (ecosystem services and food security) of the HLP baseline assessments $[27,28]$, to generate a Land-Water-Food nexus map of the Mahakanumulla 
VTCS presented in Figure 8. Data and information presented in the map were validated by referring to past studies carried out in the study area, the resource profile of the Mahakanumulla VTCS, and aerial drone images used in the field assessments and GIS spatial analysis. The nexus map revealed that many interactions between critical subsystems of the VTCS are new and have not yet been adequately studied.

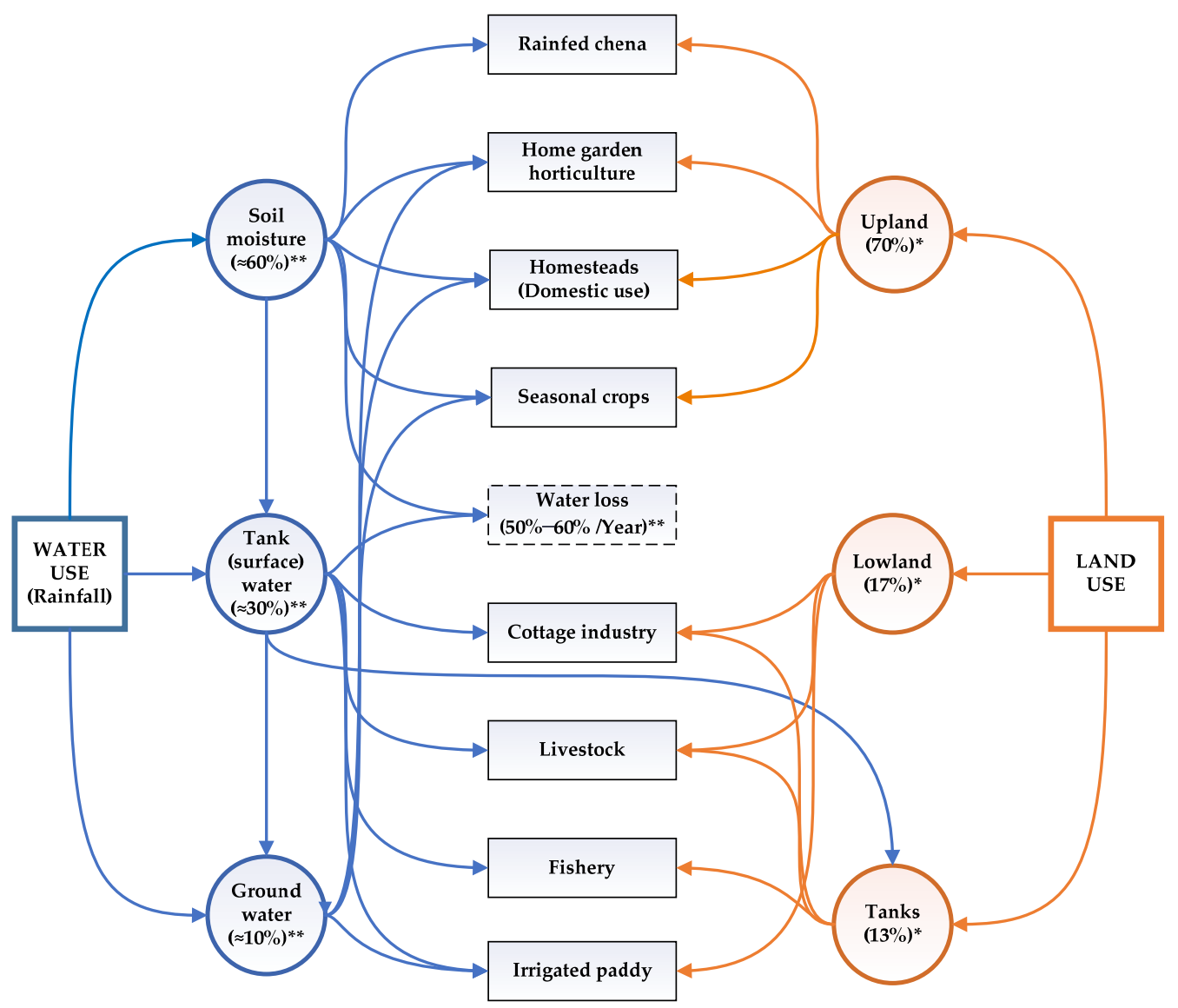

Figure 8. Land-Water-Food security nexus in the Mahakanumulla VTCS. * GIS spatial analysis, ${ }^{* *}$ Data from [31,48,49].

The village tank is a seasonal small reservoir, and most of its storage is replenished from surface inflow generated from the tank catchment area. Forest vegetation in the tank catchment area absorbs rainfall and gradually releases water into the tank system. In addition, a shallow regolith aquifer found in the dry zone landscape is replenished with rainfall and maintained by the VTCSs, which brings an additional benefit. The subsurface flow of groundwater feeds command areas situated in lower areas of the valley supporting paddy cultivation [34]. Further, groundwater is utilized through agro-wells for irrigation in the upland seasonal crops farming [50-52] and domestic purposes through shallow domestic wells in homesteads $[34,53]$.

The stored water is lost not only due to irrigation but also from evaporation, evapotranspiration, seepage, percolation and bund leakages. Water losses from the catchment, tanks, canals, and fields are found to be more than that used for farming. Studies have revealed that in an average year about $50-60 \%$ of the total tank water storage is lost without any apparent use for downstream command area paddy cultivation [49,54]. About 20-30\% of wet seasonal (Maha) precipitation from the upstream catchment contributes to the tank water storage. Considering factors of water loss and conveyance efficiency $(80 \%)$, only $13 \%$ of the wet seasonal (Maha) precipitation is available for command area paddy cultivation [31]. A study found that the total tank water loss from the Mahakanumulla VTCS during a dry month is about $12 \%$ of the total tank storage [55]. Tank characteristics (shape, water spread area, water depth, tank bund condition, tank bed geometry, location of the 
tank, condition of the tank associated micro-land uses) and the catchment characteristics (slope, size, shape, vegetation cover, soil condition) affect the tank water balance of the VTCS [54]. Loss of land productivity by various forms of land degradation is a major cause for reduction in crop and livestock production [56]. Diminishing surface and groundwater quality due to human-induced activities, such as the excessive use of pesticides, fertilizer, detergents, and waste dumping $[7,24,25,57]$, can be considered major threats to human health and sustainability of the system $[13,55,58]$. Surrounding vegetation in the microland-use components of the tank significantly contributes to the ecological balance in land and water resources of the VTCS.

\subsubsection{Climate Change and Food Security Nexus}

The climate change and the food production nexus of the system provide many challenges and substantial trade-offs in terms of VTCSs sustainability [59,60]. Climate change increases the likelihood of extreme climatic events and is identified as a major driver that impacts food security and nutrition of the socio-ecological production landscapes [61-69]. The study adopted the climate change impact chain approach (http: / / cigrasp.pik-potsdam.de/about/ impactchains, accessed on 6 March 2021) to map climate-related impacts on resource subsystems of Mahakanumulla VTCS. The study analysed the participatory assessments data and information of the HLP baseline assessment linked with the findings of past studies carried out in the VTCSs landscapes to identify the climate-food nexus illustrated in Figure 9. Data and information presented in the map were validated through online expert and key informant opinion consultation. The climate-food nexus map clearly illustrates the possible impact of climate change and changes of VTCS land uses that have taken place recently on ecosystem health (agro-biodiversity and wild biodiversity) and human wellbeing (human health, food and nutrition security, livelihood avenues, and human-wildlife coexistence).

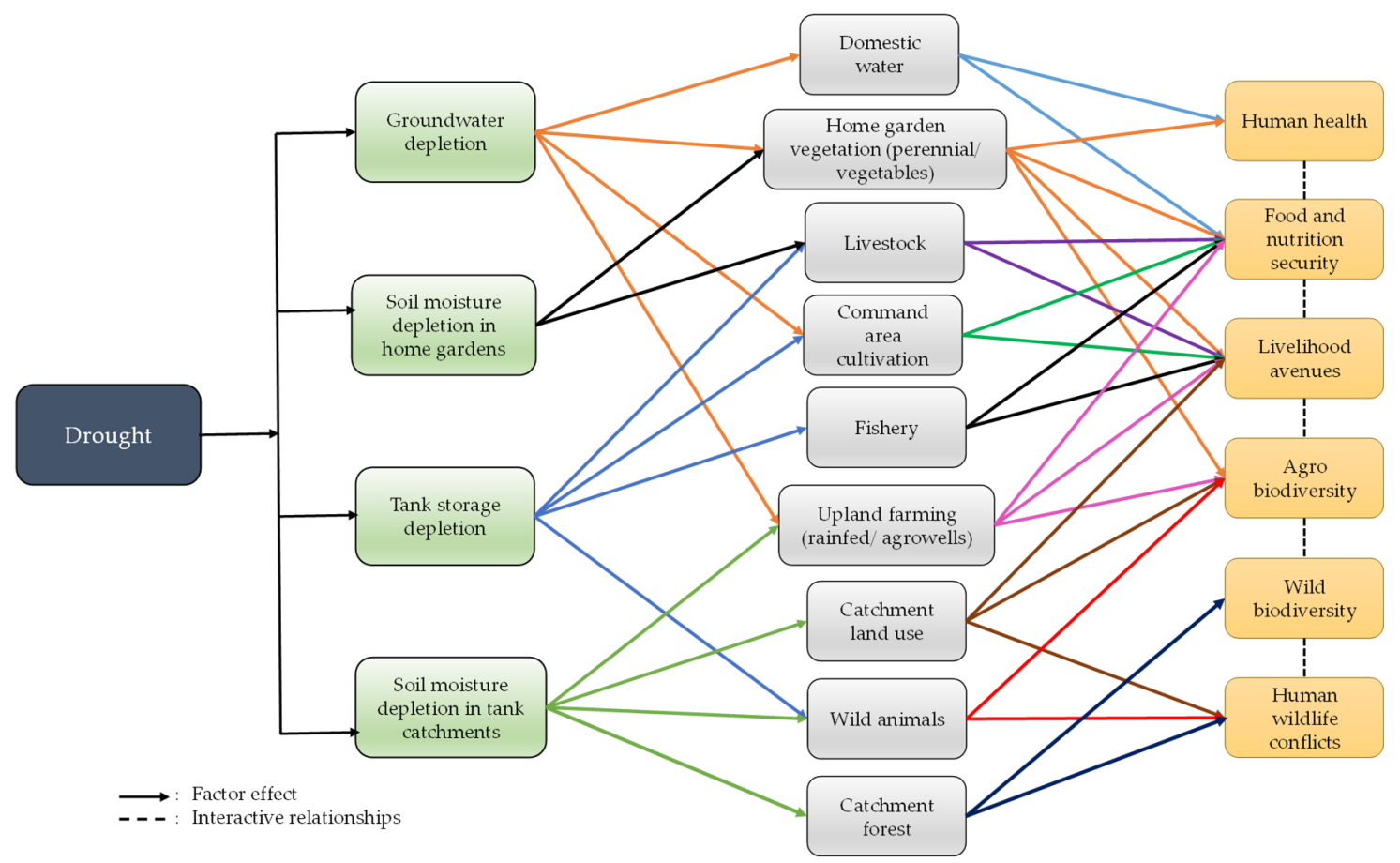

Figure 9. Climate-Biodiversity-Food and livelihood nexus in the Mahakanumulla VTCS.

The farming patterns of the VTCSs have been adopted to ensure biodiversity conservation, food security, and adaptation to climatic changes. Links between agrobiodiversity and wild biodiversity in the context of climate change and food production in the VTCSs are important; thus, food production and biodiversity conservation may not necessarily 
be opposed to one another in the VTCS [70]. However, they should be better integrated for achieving optimum outcomes to overcome climate change impacts. In this context, a system-based analysis approach is essential to identify the climate-food-biodiversity nexus [71].

The multifaceted nature of the VTCS provides diverse livelihood opportunities to the local communities. In the Mahakanumulla VTCS, the three different farming systems that have been practised to adapt to climate change variations are (i) irrigated paddy cultivation in the tank command area, (ii) shifting cultivation (Chena) and other diverse seasonal field crops farming in the upstream communal lands under rain-fed conditions and irrigation through agro-wells, and (iii) perennial crops, mostly multipurpose trees in home gardens that utilize mainly subsurface soil moisture [48]. Collectively, these farming systems have maintained a high level of genetic diversity of traditional crop varieties and livestock breeds that enhance the climate resilience of the farming systems. It is believed that a majority of the genetic diversity of rice, including wild relatives, can be traced from these VTCS farming landscapes [72]. Additionally, various agroecological practices adapted by farmers are important to maintain agrobiodiversity and adapt to climate change impacts.

Home gardens in the VTCS landscape are well adapted to climate change shocks and bear high food variety diversity, particularly neglected and underutilized fruit species, edible medicinal plants, indigenous vegetable varieties, tuber crops and spices. The soil moisture in these home gardens is retained for a long period, and horticulture is practised successfully throughout the year [73]. Further, other livelihood options such as animal husbandry, beekeeping, cottage industries, ornamental plant species, and agroforestry are practised to meet nutritional and livelihood needs [74]. However, the full potential of socio-ecological benefits of existing home gardens to sustain climate change impacts have not been fully realized.

\subsubsection{Biocultural Diversity, Ecosystem Services and Traditional Knowledge Nexus}

VTCSs can be recognized as locally adapted traditional agricultural systems. These systems are based on rich traditional knowledge and are known to have symbiotic relationships between biodiversity and cultural elements, also referred to as bio-cultural diversity [75]. Thus, the evidence of the relationships can be established between biological diversity and cultural practices of the landscape. Traditional knowledge and biodiversity are the key indicators for recognizing GIAHSs and SESPLs established by the FAO [76] and the Satoyama initiative [77] in different regions of the world. The study used the concept of biocultural diversity [78] integrating an ES approach [79], and blended data and information generated from the field assessments and surveys of the HLP (biodiversity, traditional knowledge, food security, ES and medicinal plants) [28] to unveil relationships between biocultural elements in the Mahakanumulla VTCS as illustrated in Figure 10.

The traditional knowledge system (TKS) found in the VTCS, is a combination of the traditional wisdom that has been pursued from long-term challenging experiences with an assemblage of intergenerational effects and natural phenomena from cultural and spiritual roots. Various biophysical components of the VTCS are demonstrated in traditional knowledge, which is essential for the conservation and use of biodiversity and the continuous flow of ES linked with these components. [80,81]. Traditional knowledge practised in the VTCS is associated with agrobiodiversity and wild biodiversity for food production and medicinal plant resources for the traditional medical system (Ayurveda). Although VTCS landscapes have provided a broad range of variety of wild edible plants with medicinal properties, the value of "hidden biodiversity," which could be of potential value for human health and nutrition is still poorly understood. Field assessments of the HLP revealed that TKS is still used in the VTCS to enhance adaptability and resilience to climate variability, integrating agrobiodiversity and traditional medical practices [27,28,82-84]. Around the time of the Green Revolution (1960s), the traditional knowledge practised in these agricultural systems was gradually eroded by the promotion of high-input intensive farming practices, leading to the gradual disappearance of the TKS [30]. However, some of the elements of 
the TKS in VTCSs still exist and function to a certain degree, despite the forces of global environmental change $[6,83,85]$.

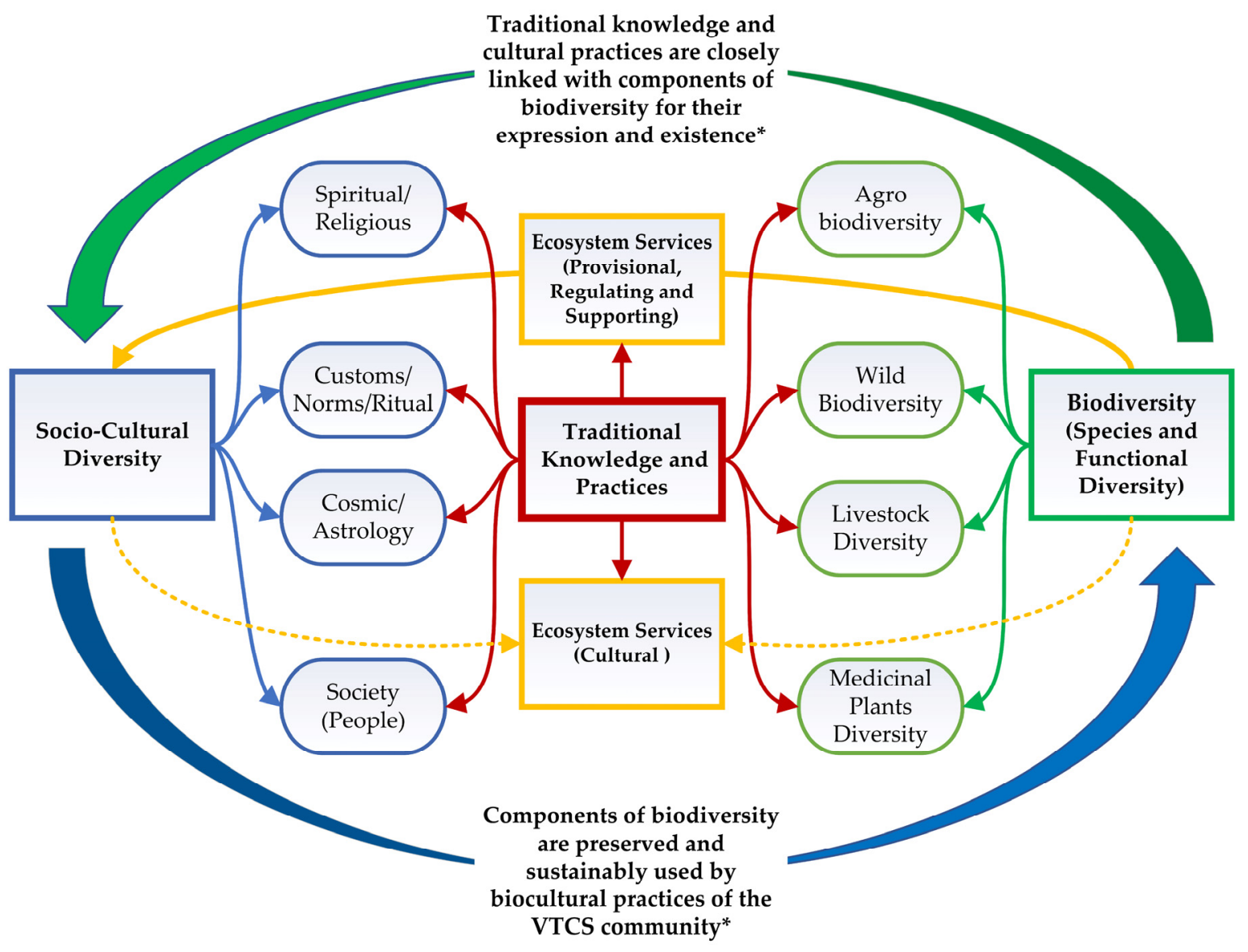

Figure 10. Biocultural diversity, ecosystem services and traditional knowledge nexus in the Mahakanumulla VTCS. * Adopted from [78].

The disappearance of such knowledge and practices within the system is considered one of the major challenges for the sustainability of VTCSs. Identification of TKS values and quantifying specific biocultural elements (i.e., the "social-ecological keystone" relationships concept) [86] is an important aspect of the VTCS resilience that depends on the ability to adapt in the face of climate change without sacrificing biological and cultural wealth and its productive capacity [78].

\subsection{Productivity Issues, Linked with Socio-Ecological Properties and Restoration Challenges}

Proper understanding of social and ecological elements and their relationships to climatic and non-climatic stresses due to changing climate and land use/cover (LULC) is essential to ensure the sustainability of VTCS restoration projects. These stresses have caused the ecological imbalance of the VTCS, challenging its sustainability and resilience in the context of food production and socio-ecological values. During the past two decades, the integrity and functions of VTCSs have been degraded significantly affecting the provision of ecosystem goods and services. For example, deterioration of micro-land use components and upstream catchment forest has had a significant impact on biotic diversity (species diversity, functional diversity and vegetation structure), abiotic heterogeneity (soil erosion and land degradation) and imbalance of water budget (soil moisture, evaporation, surface runoff), leading to a significant reduction in the capacity of supplying and regulating ES in the VTCS [87-90]. Thus, the study examined the identified causal factors and their interactive relationships $[27,28]$ within the framework of resilience, adaptive capacity, 
and the vulnerability (RACV) concept [29], while incorporating exposure and sensitivity indices specific to Mahakanumulla VTCS. The process is illustrated in Figure 11.

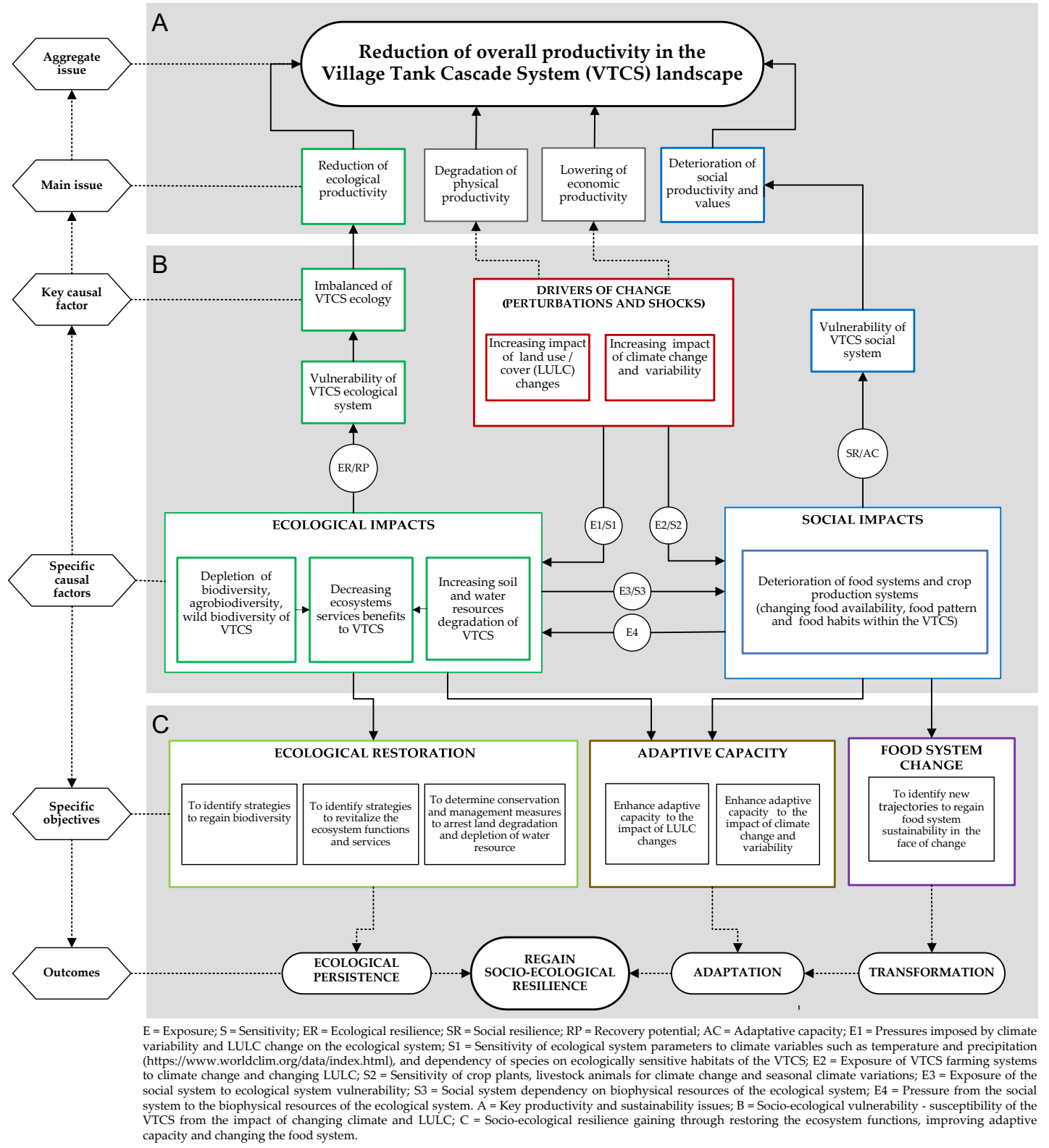

Figure 11. Comprehensive illustration of causal factors and processes leading to reduction of overall productivity of the VTCS landscape.

It was observed that climate, LULC and demographic changes increase the exposure (E) and sensitivity (S) of the ecological system, disturbing the continuous supply of ES to the social system. This creates ES supply and demand mismatches in food production in the VTCS.

Recent studies have shown that various factors impact the ecological productivity of the VTCSs. For instance, agricultural expansion into ecologically sensitive areas of the major VTCS zones due to demographic changes and urbanization has led to a drastic reduction in forest cover during the last two decades $[8,89,90]$. The degradation of the integrity and functionality of the cascade ecology has resulted in the reduction of capacity to supply ES and increased severity of droughts [6]. Further, likely increased infestation of aquatic invasive alien plants in village tanks under climate variability can result in considerable ecological and socio-economic productivity losses [91]. Over-reliance on agrochemicals and 
subsidized fertilizer have caused major impacts on the VTCS environment, particularly on soil and aquatic biodiversity. The negative effect of agrochemicals and fertilizer on water and soil properties and human health have been well documented [92-94].

Increasing incidences of extreme climate events will further aggravate the situation challenging the system $[95,96]$. Climate change influences the amount, pattern and intensity of rainfall, affecting the water availability and cropping pattern in the VTCS [97]. Heavy rains due to extreme climate events generate very high runoff during shorter periods, mainly due to poor management of catchment forests that increases soil erosion and tank sedimentation. The traditional knowledge system is also a heavily influential element in the VTCS [82] but has been neglected in the applications of climate change adaptation and mitigation measures [96]. The combination of all these factors ultimately contributes to lower the cropping intensity, causing farming systems to be less productive and less resilient $[6,90,98]$.

Though criteria have been developed to evaluate various landscape systems, such as SESPLs and GIAHSs found in different parts of the world [76,77], there is a need to develop more comprehensive elaborations of ensembles and anatomies of them in order to make recommendations to prepare detailed dynamic conservation and productivity improvement plans. Due to the high diversity and complexity of these landscapes, it would be difficult to understand the whole process by examining a single resource system using a specific dimension of landscape characteristics [99]. Based on the findings and discussions, the present study provides a framework that could be used as a general guideline and to develop indicators applicable to other landscape systems in the tropical earth zones of the world.

\section{Conclusions}

Proper and systematic exploration of various landscape dimensions and properties will enable opportunities for a better understanding of highly diverse socio-ecological systems such as VTCSs from different perspectives of sustainability. Accordingly, the main findings and recommendations of the study are as follows:

- The study provides a mix-approach framework to intersect and analyse resource subsystems and a socio-ecological nexus that can help establish better sustainability solutions to enhance the overall productivity of the VTCS.

- Increasing climate variability and changes in LULC are the key causal factors for the reduction of ecological and socio-economic productivity of the VTCS.

- Climatic and LULC changes increase the exposure and vulnerability of the ecological system disturbing the continuous supply of ES to the social system. This creates ES supply and demand imbalance in food production of the VTCS.

- Ensemble of tank environs is significant for providing regulatory and supporting ES and synergistic relationships with the provisional ES of the VTCS.

- Effect of functional diversity on the ensemble of tank environs is significant for maintaining the ecological persistence that strongly determines the ecological productivity of the VTCS.

- The study characterized an important socio-ecological nexus that contributes to sustainable food production in the VTCS. The land-water-food nexus map revealed that many interactions between critical subsystems of the VTCS are new and have not yet been studied adequately.

- The climate-food nexus indicates the possible impact of climate change and changes of VTCS land uses that have taken place recently on ecosystem health and human well-being.

- Land-water-climate-food nexus revealed that the drought-related climatic parameters affect the soil moisture content and reduce the upland farming systems productivity. Thus, in-situ conservation of soil moisture in the upland farming lands is critical for maintaining productivity in the VTCS. 
- The fact that the VTCS landscape provides habitat for a wide range of diversity of wild edible and medicinal plants, which possess potential value for human health and nutrition, their contribution as such is still poorly understood.

- Geospatial analysis indicated that the river basins, which contain the majority of the cascade systems, do not have direct surface hydrological connectivity with the central mountainous land massif of the country. Further studies are required to clarify what is behind this phenomenon.

- The sustainability of the VTCS depends on the optimum function level of cascade anatomy and socio-ecological nexus. Thus, future research on VTCSs needs to integrate socio-economic and ecological variables from various biophysical components of the VTCS with detailed multi-tier characterization and mapping, which can influence optimum ecological restoration.

Author Contributions: Conceptualization, S.S.R. and P.B.D.; Data curation, S.S.R. and H.K.K.; Formal analysis, S.S.R. and H.K.K.; Investigation, S.S.R.; Methodology, S.S.R. and L.K.; Software, S.S.R. and H.K.K.; Validation, S.S.R., L.K., P.B.D. and D.H.; Visualization, S.S.R. and H.K.K.; Writing-original draft, S.S.R.; Writing—review \& editing, S.S.R., L.K., P.B.D., C.S.K. and D.H.; Supervision, L.K. All authors have read and agreed to the published version of the manuscript.

Funding: This research was supported by an Australian Government Research Training Program (RTP) and Destination Australia Program (DAP) Scholarships through the University of New England (UNE), Australia to the first author.

Institutional Review Board Statement: Not applicable.

Informed Consent Statement: Not applicable.

Data Availability Statement: Not applicable.

Acknowledgments: The authors acknowledge Benjamin Kipkemboi Kogo, School of Rural and Environment Sciences, UNE for assisting in editing the technical content of the paper. The authors also acknowledge the South Asia Co-operative Environment Programme (SACEP), Sri Lanka and Alliance of Bioversity International and CIAT, Italy for providing secondary information and support for on-site field assessments through the 'Healthy Landscapes Project'.

Conflicts of Interest: The authors declare no conflict of interest.

\section{References}

1. Beckers, B.; Berking, J.; Schütt, B. Ancient water harvesting methods in the drylands of the Mediterranean and Western Asia. eTopoi. J. Anc. Stud. 2013, 2, 145-164.

2. Chinnasamy, P.; Srivastava, A. Revival of traditional cascade tanks for achieving climate resilience in drylands of South India. Front. Water 2021, 3, 35. [CrossRef]

3. Ariyananda, T. Transforming Tradition of Rainwater Harvesting in Sri Lanka. In International Rainwater Catchment Systems Experiences; Espíndola, J.A.G., Flores, C.A.C., Pacheco-Vega, R., Montes, M.R.P., Eds.; IWA Publishing: London, UK, 2020; pp. 41-54.

4. Srivastava, A.; Chinnasamy, P. Water management using traditional tank cascade systems: A case study of semi-arid region of Southern India. SN Appl. Sci. 2021, 3, 281. [CrossRef]

5. Madduma Bandara, C.M. Catchment ecosystems and village Tank Cascades in the dry zone of Sri Lanka a time-tested system of land and water resource management. In Strategies for River Basin Management; Lohm, U., Lundqvist, J., Falkenmark, M., Eds.; Springer: Dordrecht, The Netherlands, 1985; Volume 6, pp. 99-113.

6. Dharmasena, P.B. Cascaded Tank-Village System: Present Status and Prospects. In Agricultural Research for Sustainable Food Systems in Sri Lanka; Springer: Singapore, 2020; pp. 63-75.

7. Mahatantila, K.; Chandrajith, R.; Jayasena, H.A.; Ranawana, K.B. Spatial and temporal changes of hydrogeochemistry in ancient tank cascade systems in Sri Lanka: Evidence for a constructed wetland. Water Environ. J. 2008, 22, 17-24. [CrossRef]

8. Abeywardana, N.; Schütt, B.; Wagalawatta, T.; Bebermeier, W. Indigenous agricultural systems in the dry zone of Sri Lanka: Management transformation assessment and sustainability. Sustainability 2019, 11, 910. [CrossRef]

9. Welgama, N.; Wanigasundera, W. The Impact of Rehabilitation Approaches in the Sustainability of the Management of Small Tanks in Sri Lanka. Int. J. Econ. Manag. Eng. 2012, 6, 3744-3753.

10. FAO. “Globally Important Agricultural Heritage Systems” (GIAHS). 2021. Available online: http://www.fao.org/giahs/en/ (accessed on 26 January 2021). 
11. GCF. Green Climate Fund (GCF) Project on Strengthening the Resilience of Smallholder Farmers in the Dry Zone to Climate Variability and Extreme Events through an Integrated Approach to Water Management. 2021. Available online: https://www. greenclimate.fund/project/fp016?inheritRedirect=true\&redirect=/projects/browse-projects (accessed on 26 January 2021).

12. Clark, R.; Reed, J.; Sunderland, T. Bridging funding gaps for climate and sustainable development: Pitfalls, progress and potential of private finance. Land Use Policy 2018, 71, 335-346. [CrossRef]

13. Mahatantila, K.; Chandrajith, R.; Jayasena, H.A.; Marasinghe, S. Water Quality Variation in a Tank Cascade Irrigation System: A Case Study from Malagane Cascade, Sri Lanka. In Survival and Sustainability; Springer: Berlin, Germany, 2010; pp. 1345-1353.

14. Dharma-Wardana, M.W.; Amarasiri, S.L.; Dharmawardene, N.; Panabokke, C.R. Chronic kidney disease of unknown aetiology and ground-water ionicity: Study based on Sri Lanka. Environ. Geochem. Health 2015, 37, 221-231. [CrossRef] [PubMed]

15. Dharmasena, P. Soil Erosion Control Measures for Rain-Fed Farming in the Dry Zone of Sri Lanka. Ph.D. Thesis, University of Peradeniya, Peradeniya, Sri Lanka, 1992.

16. Jayatilaka, C.J.; Sakthivadivel, R.; Shinogi, Y.; Makin, I.W.; Witharana, P. A simple water balance modelling approach for determining water availability in an irrigation tank cascade system. J. Hydrol. 2003, 273, 81-102. [CrossRef]

17. Jayakody, B.; Mowjood, M.; Gunawardena, E. Modifying and testing of a cascade water balance model using a mini cascade system with two tanks. Trop. Agric. Res. 2004, 16, 159-170.

18. Matsuno, Y.; Tasumi, M.; van der Hoek, W.; Sakthivadivel, R.; Otsuki, K. Analysis of return flows in a tank cascade system in Sri Lanka. Paddy Water Environ. 2003, 1, 173-181. [CrossRef]

19. Perera, K.T.; Wijayaratna, T.M.; Jayatillake, H.M.; Manatunge, J.M.; Priyadarshana, T. Hydrological principle behind the development of series of bunds in ancient tank cascades in small catchments, Sri Lanka. Water Pract. Technol. 2020, 15, 1174-1189. [CrossRef]

20. Sakthivadivel, R.; Brewer, J.D. Water resources development planning in a basin context in the absence of good hydrologic data: An example from Sri Lanka. Int. J. Water Resour. Dev. 1999, 15, 73-91. [CrossRef]

21. Molden, D.; Sakthivadivel, R. Water accounting to assess use and productivity of water. Int. J. Water Resour. Dev. 1999, 15, 55-71. [CrossRef]

22. Izumi, A.; Hori, T. Applicability of Water Level Monitoring System and Water Level Estimation System to Tank Cascade in Sri Lanka. Jpn. Agric. Res. Q. 2021, 55, 35-43. [CrossRef]

23. Wijesundara, W.; Nandasena, K.; Jayakody, A. Seasonal and spatial variations of N, P, K and Cd concentrations in water of the Mahakanumulla cascade in the dry zone of Sri Lanka. Trop. Agric. Res. 2013, 24, 279-288. [CrossRef]

24. Wijesundara, W.; Nandasena, K.; Jayakody, A. Spatial and Temporal Changes in Nitrogen, Phosphorus and Potassium Concentration in Water in the Thirappane Tank Cascade in Dry Zone of Sri Lanka. J. Environ. Prof. Sri Lanka 2012, 1, 70-81. [CrossRef]

25. Chandrajith, R.; Mahatantila, K.; Jayasena, H.A.; Tobschall, H.J. Geochemical characteristics of sediments from a reservoir (tank) ecosystem in Sri Lanka. Paddy Water Environ. 2008, 6, 363-371. [CrossRef]

26. Schütt, B.; Bebermeier, W.; Meister, J.; Withanachchi, C.R. Characterisation of the Rota Wewa tank cascade system in the vicinity of Anuradhapura, Sri Lanka. DIE ERDE-J. Geogr. Soc. Berl. 2013, 144, 51-68.

27. HLP-PPG. Project Preparatory Grant (PPG) Report of the UNEP-GEF Project on 'Healthy Landscapes: Managing Agricultural Landscapes in Socio-Ecologically Sensitive Areas to Promote Food Security, Well-Being and Ecosystem Health'; Hunter, D., Ed.; Global Environment Facility (GEF): Washington, DC, USA, 2018; p. 140.

28. HLP-BLA. Baseline Assessment Report of the Healthy Landscapes Project (UNEP-GEF): Managing Agricultural Landscapes in SocioEcologically Sensitive Areas to Promote Food Security, Well-Being and Ecosystem Health; Dharmasena, P.B., Kadupitiya, H.K., Ratnayake, S.S., Eds.; South Asia Co-operative Environment Programme (SACEP) and Alliance of Bioversity International and CIAT: Colombo, Sri Lanka, 2020.

29. Gallopín, G.C. Linkages between vulnerability, resilience, and adaptive capacity. Glob. Environ. Chang. 2006, 16, 293-303. [CrossRef]

30. Dharmasena, P.B. Evolution of hydraulic societies in the ancient Anuradhapura Kingdom of Sri Lanka. In Landscapes and Societies; Springer: Heidelberg, Germany, 2010; pp. 341-352.

31. Navaratne, W.M.U. Contribution of small tanks to upkeep the village community. In Food Security and Small Tank Systems in Sri Lanka; National Science Foundation: Colombo, Sri Lanka, 2000.

32. Katupotha, J.; Gamage, S. Understanding the river basin classification of Sri Lanka. Wildlanka 2020, 8, 175-197.

33. Wijesundara, W.M.G.D.; Nandasena, K.A.; Jayakody, A.N. Hydro-chemical status of the Mahakanumulla cascade in the dry zone Sri Lanka. J. Soil Sci. Soc. Sri Lanka 2014, 24, 15-20.

34. Panabokke, C.R.; Perera, A.P.G.R.L. Groundwater Resources of Sri Lanka; Water Resources Board: Colombo, Sri Lanka, 2005 ; p. 28.

35. Dissanayake, C.; Chandrajith, R. The hydrogeological and geochemical characteristics of groundwater of Sri Lanka. In Groundwater of South Asia; Springer: Singapore, 2018; pp. 405-428.

36. Itakura, J. Water Balance Model for Planning Rehabilitation of a Tank Cascade Irrigation System in Sri Lanka; IWMI: Colombo, Sri Lanka, 1995; p. 63.

37. Dharmasena, P.B. Essential components of traditional village tank systems. In Proceedings of the National Conference on Cascade irrigation Systems for Rural Sustainability; Central Environmental Authority: Battaramulla, Sri Lanka, 2010. 
38. Geekiyanage, N.; Pushpakumara, D. Ecology of ancient tank cascade systems in island Sri Lanka. J. Mar. Isl. Cult. 2013,2 , 93-101. [CrossRef]

39. Dharmasena, P.B. Environmental richness in the dry zone home gardens. In Multipurpose Tree Species in Sri Lanka: Multipurpose trees for Environment Conservation, Proceedings of the Eighth National Workshop on Multipurpose Trees, Kandy, Sri Lanka, 23-25 October 1997; University of Peradeniya: Peradeniya, Sri Lanka, 1998.

40. Williams, J. Metrics for assessing the biodiversity values of farming systems and agricultural landscapes. Pac. Conserv. Biol. 2004, 10, 145-163. [CrossRef]

41. Jeanneret, P.; Schüpbach, B.; Luka, H. Quantifying the impact of landscape and habitat features on biodiversity in cultivated landscapes. Agric. Ecosyst. Environ. 2003, 98, 311-320. [CrossRef]

42. Li, H.; Wu, J. Use and misuse of landscape indices. Landsc. Ecol. 2004, 19, 389-399. [CrossRef]

43. Duelli, P. Biodiversity evaluation in agricultural landscapes: An approach at two different scales. Agric. Ecosyst. Environ. 1997, 62, 81-91. [CrossRef]

44. Thompson, I.D. An overview of the science-policy interface among climate change, biodiversity, and terrestrial land use for production landscapes. J. For. Res. 2015, 20, 423-429. [CrossRef]

45. Alessandra, A.; Daniel, C.; Ivo, H.; United Nations Statistics Division; Jean Louis Weber; European Environmental Agency. Note on Definition of Socio-Ecological Landscape Unit, SELU Classification and Its Policy Application; European Environmental Agency: Copenhagen, Denmark, 2011.

46. Yang, Y.; Bai, K.; Li, G.; Jarvis, D.I.; Long, C. Assessment of the Resilience in SEPLS (Socio-Ecological Production Landscapes and Seascapes) in Yanuo Village, Xishuangbanna, Southwest China. Sustainability 2020, 12, 3774. [CrossRef]

47. IPSI. The International Partnership for the Satoyama Initiative (IPSI): Information Booklet and 2017 Annual Report; United Nations University Institute for the Advanced Study of Sustainability (UNU-IAS): Tokyo, Japan, 2018.

48. Dharmasena, P.B. Tank village system as a resource base for multi-purpose trees. In 5th Regional Workshop on Multi-Purpose Trees; Gunasena, H., Ed.; University of Peradeniya: Peradeniya, Sri Lanka, 1994; pp. 8-19.

49. Dharmasena, P.B. Present use of land and water resources in village tank farming: A case study in Mahakanumulla cascade. J. Soil Sci. Soc. Sri Lanka 1991, 7, 1-17.

50. Kumari, M.K.; Sakai, K.; Kimura, S.; Yuge, K.; Gunarathna, M.H. Classification of Groundwater Suitability for Irrigation in the Ulagalla Tank Cascade Landscape by GIS and the Analytic Hierarchy Process. Agronomy 2019, 9, 351. [CrossRef]

51. Senaratne, A.; Wickramasinghe, K. Commons vs. Commons: Managing Scarce Water Resources in Dry Zone Village Tank Systems in Sri Lanka; EEPSEA: Ho Chi Minh City, Vietnam, 2011.

52. Panabokke, C.R.; Sakthivadivel, R.; Weerasinghe, A.D. Evolution, Present Status and Issues Concerning Small Tank Systems in Sri Lanka; International Water Management Institute: Colombo, Sri Lanka, 2002.

53. Rekha, N.; Jayakumara, M. Progress of Research on Cascade Irrigation Systems in the Dry Zones of Sri Lanka. In Water Communities; Shaw, R., Thaitakoo, D., Eds.; Emerald Group Publishing Limited: Bingley, UK, 2010; pp. 109-137.

54. Dharmasena, P.B. Towards efficient utilization of surface and groundwater resources in food production under small tank system. In Food Security and Small Tank Systems in Sri Lanka; National Science Foundation: Colombo, Sri Lanka, 2000.

55. Dharmasena, P.B. System loss studies of village tanks. Trop. Agric. 1985, 141, 95-108.

56. Le, Q.B.; Nkonya, E.; Mirzabaev, A. Biomass Productivity-Based Mapping of Global Land Degradation Hotspots. In Economics of Land Degradation and Improvement-A Global Assessment for Sustainable Development; Nkonya, E., Mirzabaev, A., von Braun, J., Eds.; Springer: New York, NY, USA, 2016; pp. 55-84.

57. Abeysingha, N.; Dassanayake, K.; Weerarathna, C. Will restoration of ecological functions of tank cascade system contribute to reduce CKDu in Sri Lanka? A review. Environ. Manag. Sustain. Dev. 2018, 7, 60-81. [CrossRef]

58. IUCN. Project Implementation Plan. IUCN Programme on Restoring Traditional Cascading Tank Systems Technical Note \# 1; IUCN, International Union for Conservation of Nature: Colombo, Sri Lanka, 2015; p. 34.

59. Béné, C.; Prager, S.D.; Achicanoy, H.A.; Toro, P.A.; Lamotte, L.; Bonilla, C.; Mapes, B.R. Global map and indicators of food system sustainability. Sci. Data 2019, 6, 279. [CrossRef] [PubMed]

60. Dayananda, D.; Weerahewa, J.; Weerasooriya, S. Water Availability, Crop Choices and Profitability of Farming: A Case Study of Mahakanumulla Tank Village. Trop. Agric. Res. 2021, 32, 81-94. [CrossRef]

61. Singh, A.; Sharma, P. Implications of climatic and non-climatic variables on food security in developing economies: A conceptual review. MOJ Food Process. Technol. 2018, 6, 00138. [CrossRef]

62. Dharmasena, P.B. Agriculture, environment and food security in the context of rice. In Proceedings of the National Conference on Water, Food Security, and Climate Change in Sri Lanka, BMICH, Colombo, Sri Lanka, 9-11 June 2009; IWMI: Colombo, Sri Lanka, 2010; Volume 1.

63. Kogo, B.K.; Kumar, L.; Koech, R. Climate change and variability in Kenya: A review of impacts on agriculture and food security. Environ. Dev. Sustain. 2020, 23, 23-43. [CrossRef]

64. Tadese, M.T.; Kumar, L.; Koech, R.; Kogo, B.K. Perception of the impacts of climate and environmental variability on water availability, irrigation and farming systems: A study in rural households of Awash River Basin, Ethiopia. Int. J. Agric. Sustain. 2021, 19, 1-16. [CrossRef]

65. Dang, A.T.; Kumar, L.; Reid, M. Modelling the potential impacts of climate change on rice cultivation in Mekong Delta, Vietnam. Sustainability 2020, 12, 9608. [CrossRef] 
66. Alahacoon, N.; Edirisinghe, M.; Ranagalage, M. Satellite-Based Meteorological and Agricultural Drought Monitoring for Agricultural Sustainability in Sri Lanka. Sustainability 2021, 13, 3427. [CrossRef]

67. Chhogyel, N.; Kumar, L.; Bajgai, Y. Consequences of climate change impacts and incidences of extreme weather events in relation to crop production in Bhutan. Sustainability 2020, 12, 4319. [CrossRef]

68. Gopalakrishnan, T.; Hasan, M.K.; Haque, A.T.; Jayasinghe, S.L.; Kumar, L. Sustainability of coastal agriculture under climate change. Sustainability 2019, 11, 7200. [CrossRef]

69. Hasan, M.K.; Kumar, L. Yield trends and variabilities explained by climatic change in coastal and non-coastal areas of Bangladesh. Sci. Total. Environ. 2021, 795, 148814. [CrossRef]

70. Hunter, D.; Guarino, L.; Spillane, C.; McKeown, P.C. Routledge Handbook of Agricultural Biodiversity; Routledge: New York, NY, USA, 2017.

71. French Collier, N.; Sayer, J.; Boedhihartono, A.K.; Hanspach, J.; Abson, D.; Fischer, J. System properties determine food security and biodiversity outcomes at landscape scale: A case study from West Flores, Indonesia. Land 2018, 7, 39. [CrossRef]

72. Liyanage, A.S.U. Eco-Geographic Survey of Crop Wild Relatives. In Situ Conservation of Crop Wild Relatives through the Enhanced Information Management and Field Application Project; Plant Genetic Resources Centre, Department of Agriculture: Peradeniya, Sri Lanka, 2010.

73. Gu, H.; Subramanian, S.M. Drivers of change in socio-ecological production landscapes: Implications for better management. Ecol. Soc. 2014, 19, 41. [CrossRef]

74. Ichikawa, K. Socio-Ecological Production Landscapes in Asia; United Nations University Institute of Advanced Studies (UNU-IAS): Tokyo, Japan, 2012.

75. CBD. Glossary of Relevant Key Terms and Concepts within the Context of Article 8(j) and Related Provisions. 2017. Available online: https:/ / www.cbd.int/doc/c/03e6/17df/da9bb92bc05355119598a511/wg8j-10-1-03-en.pdf (accessed on 10 March 2021).

76. Arnés García, M.; Yagüe, J.L.; de Nicolás, V.L.; Díaz-Puente, J.M. Characterization of Globally Important Agricultural Heritage Systems (GIAHS) in Europe. Sustainability 2020, 12, 1611. [CrossRef]

77. Dublin, D.; Natori, Y.; Takahashi, Y.; Lopez-Casero, F. SEPLS: Socio-Ecological Production Landscapes and Seascapes Experiences Overcoming Barriers from around the World: GEF Satoyama Project; Conservation International: Tokyo, Japan, 2018 ; p. 8.

78. Bridgewater, P.; Rotherham, I.D. A critical perspective on the concept of biocultural diversity and its emerging role in nature and heritage conservation. People Nat. 2019, 1, 291-304. [CrossRef]

79. MEA. Millennium Ecosystem Assessment: Ecosystems and Human Well-Being; Island Press: Washington, DC, USA, $2005 ;$ Volume 5.

80. Rekha, N.; Dharmasena, P.B. Indigenous knowledge of farming practices and water management in the dry zone of Sri Lanka. In Indigenous Knowledge and Disaster Risk Reduction, from Practice to Policy; Nova Publisher: New York, NY, USA, 2009 ; pp. 329-348.

81. Bergamini, N.; Blasiak, R.; Eyzaguirre, P.B.; Ichikawa, K.; Mijatovic, D.; Nakao, F.; Subramanian, S.M. Indicators of Resilience in Socio-Ecological Production Landscapes (SEPLs); United Nations University Institute of Advanced Studies (UNU-IAS): Tokyo, Japan, 2013.

82. Goonatilake, S.d.A.; Ekanayake, S.P. Traditional Knowledge Use in Sri Lankan Agroecosystems for Livelihoods and Adaptation to Climate Change; BACC Project, Department of Agriculture: Peradeniya, Sri Lanka, 2016.

83. Goonatilake, S.d.A.; Ekanayake, S.P.; Wadugodapitiya, A. Biodiversity and Ethnobiology of the Kapiriggama Small Tank Cascade System in Sri Lanka; IUCN, Sri Lanka Country Office: Colombo, Sri Lanka, 2015.

84. Ratnayake, S.S.; Kariyawasam, C.S. Conservation and Use of Wild-Harvested Medicinal Plants in Sri Lanka. In Crop Wild Relative Conservation and Use; Maxted, N., Ford-Lloyd, B., Kell, S., Iriondo, J., Dulloo, M.E., Turok, J., Eds.; CABI: Oxfordshire, UK, 2008; pp. 625-630.

85. FAO. The Cascaded Tank Village System (CTVS) in the Dry Zone of Sri Lanka: A Proposal for Declaration as a Globally Important Agricultural Heritage Systems (GIAHS) Initiative; Ministry of Agriculture and Food and Agriculture Organization of the United Nations, Sri Lanka: Colombo, Sri Lanka, 2016; p. 70.

86. Winter, K.B.; Lincoln, N.K.; Berkes, F. The Social-Ecological Keystone Concept: A quantifiable metaphor for understanding the structure, function, and resilience of a biocultural system. Sustainability 2018, 10, 3294. [CrossRef]

87. Dharmasena, P.B. Ecosystem Health and Human Health in the Dry Zone of Sri Lanka: With Special Reference to Cascaded Tank Village Systems. In Field Assessment Report of the UNEP-GEF Project on 'Healthy Landscapes: Managing Agricultural Landscapes in Socio-Ecologically Sensitive Areas to Promote Food Security, Well-Being and Ecosystem Health'; Ministry of Environment: Battaramulla, Sri Lanka, 2018.

88. Goswami, M.; Bhattacharyya, P.; Mukherjee, I.; Tribedi, P. Functional diversity: An important measure of ecosystem functioning. Adv. Microbiol. 2017, 7, 82. [CrossRef]

89. Ranagalage, M.; Gunarathna, M.H.; Surasinghe, T.D.; Dissanayake, D.; Simwanda, M.; Murayama, Y.; Morimoto, T.; Phiri, D.; Nyirenda, V.R.; Premakantha, K.T.; et al. Multi-Decadal Forest-Cover Dynamics in the Tropical Realm: Past Trends and Policy Insights for Forest Conservation in Dry Zone of Sri Lanka. Forests 2020, 11, 836. [CrossRef]

90. Anuradha, J.M.; Fujimura, M.; Inaoka, T.; Sakai, N. The role of agricultural land use pattern dynamics on elephant habitat depletion and human-elephant conflict in Sri Lanka. Sustainability 2019, 11, 2818. [CrossRef]

91. Kariyawasam, C.S.; Kumar, L.; Kogo, B.K.; Ratnayake, S.S. Long-Term Changes of Aquatic Invasive Plants and Implications for Future Distribution: A Case Study Using a Tank Cascade System in Sri Lanka. Climate 2021, 9, 31. [CrossRef] 
92. Rubasinghe, R.; Gunatilake, S.; Chandrajith, R. Geochemical characteristics of groundwater in different climatic zones of Sri Lanka. Environ. Earth Sci. 2015, 74, 3067-3076. [CrossRef]

93. Wimalawansa, S.J.; Wimalawansa, S.A. Impact of changing agricultural practices on human health: Chronic kidney disease of multi-factorial origin in Sri Lanka. Wudpecker J. Agric. Res. 2014, 3, 110-124.

94. Wimalawansa, S.A.; Wimalawansa, S.J. Agrochemical-related environmental pollution: Effects on human health. Glob. J. Biol. Agric. Health Sci. 2014, 3, 72-83.

95. Darshika, T.; Jayawardane, S. Future climate projections for annual and seasonal rainfall in Sri Lanka using CMIP5 models. In Proceedings of the 1st International Conference on Climate Change, Colombo, Sri Lanka, 16-17 February 2017; The International Institute of Knowledge Management (TIIKM): Nugegoda, Sri Lanka, 2017; pp. 79-85.

96. Withanachchi, S.S.; Köpke, S.; Withanachchi, C.R.; Pathiranage, R.; Ploeger, A. Water resource management in dry zonal paddy cultivation in Mahaweli River Basin, Sri Lanka: An analysis of spatial and temporal climate change impacts and traditional knowledge. Climate 2014, 2, 329-354. [CrossRef]

97. Nisansala, W.D.; Abeysingha, N.S.; Islam, A.; Bandara, A.M. Recent rainfall trend over Sri Lanka (1987-2017). Int. J. Climatol. 2020, 40, 3417-3435. [CrossRef]

98. Jamal, M.R.; Kristiansen, P.; Kabir, M.J.; Kumar, L.; Lobry de Bruyn, L. Trajectories of cropping system intensification under changing environment in south-west coastal Bangladesh. Int. J. Agric. Sustain. 2021, 19, 1-21. [CrossRef]

99. Sahle, M.; Saito, O. Mapping and characterizing the Jefoure roads that have cultural heritage values in the Gurage socio-ecological production landscape of Ethiopia. Landsc. Urban Plan. 2021, 210, 104078. [CrossRef] 